\title{
Faculty Members' Attitudes and Perceptions towards E-Publishing at the University of Jordan
}

\author{
Muhannad Al-Shboul \\ Department of Curriculum and Instruction, The University of Jordan, Amman, Jordan \\ Email: malshboul@ju.edu.jo
}

Received 12 March 2016; accepted 24 May 2016; published 27 May 2016

Copyright (C) 2016 by author and Scientific Research Publishing Inc.

This work is licensed under the Creative Commons Attribution International License (CC BY). http://creativecommons.org/licenses/by/4.0/

c) (i) Open Access

\section{Abstract}

Electronic Publishing offers many opportunities to today's users and scholars that were not available to their predecessors. Because of the multidimensional features of e-Journals, they are becoming the choice of academic as well as public library users. Technology, and particularly the Internet, has great potential for altering scholarly communication and research inhumanities, sciences, social sciences, and health sciences disciplines. Results of scholarly surveys show that there is a significant interest in e-Publication of research. Thus, this research paper investigates the attitudes and perceptions of faculty members at the University of Jordan (UJ) of current issues associated with the use of electronic publishing and perceived obstacles to their extended use for scholarly communication and publication. Specifically, the primary focus of this study is to examine and perceive how faculty members' use of electronic publications might affect their interest in publishing their own research in electronic formats; as well as to determine the contribution of scholars towards publishing in e-Journals. In order to achieve the research objectives, a questionnaire method was adopted to elicit the opinions of the faculty members; whereas personal interviews were conducted to fill in the gaps. The results of the study reveal that the majority of the faculty members prefer to publish in electronic formats refereed journals, due to the advantages of publishing in e-Journals. Furthermore, the findings show that faculty members are also concerned about the disadvantages of e-Publishing. On the basis of the findings, some suggestions have been recommended to make publishing in e-Journals more acceptable to those scholars at UJ who still do not use it, as well as to maximize the use of e-Publishing because of the advantages that it may offer.

\section{Keywords}

E-Publishing, E-Journals, Online Journals, Digital Publication, Perception, The University of Jordan 


\section{Introduction}

Research from many studies has shown that journals are the most frequently used sources of valued information for researchers. With the advent of the Internet and electronic publishing, Journals have become more easily accessible. Over the last few years, it has seen a sudden decrease in the number of print journals and an increase in the number of electronic journals (e-Journals). It is important to study the use of e-Journals and scholars' attitudes and perceptions towards electronic publishing (e-Publishing) due to the central role that e-Journals could play in scientific research. However, even though there is sometimes confusion between "e-Journals" and "ePublishing", that is, there is little to differentiate the two terms, but for the purpose of this article they will be considered synonymous.

Academics in developing countries are fast adapting to the Internet as a source of information for teaching and research. Many studies have been conducted to determine the use of e-Journals and other e-resources [1]. Manda [2] studied the use of electronic resources by academics in Tanzania; he found that the use was low, due to several major problems such as inadequate end-user training, slow connectivity, limited access to PCs, poor search skills, lack of bandwidth, and lack of funds to subscribe to scholarly and research journals. These constraints and more have hindered scholars in developing countries from fully enjoying the benefits of the Internet and e-Publishing. According to Okiki [3], e-Journals and e-Publishing have enhanced accessibility, increased usability, enhanced effectiveness, and established new ways for users in using information for more productivity in their endeavors and offer a multitude of advantages to the researchers as well as to the knowledge seekers, enabling them to get satisfied with thirst of information needs.

Recent global advances in communications infrastructure, digital media, network services, and electronic contents present transformational opportunities and fundamental challenges for traditional print-based journals. Developments in these areas appear to offer opportunities for increasing and enhancing library service offerings, reducing costs, and improving organizational performance [4].

Academic journals now have both printed as well as electronic formats in their collection. The e-Journals can be stored, accessed, and delivered as and when required; therefore the services of libraries are not confined within the four walls but are integrated into local, regional, national, and international networks. Herman [5] pointed out that integration of electronic media into academic work is progressively harnessing the new technologies to scholarly information activity of the university faculty members in an increasingly electronic environment.

So far, several reviewed studies seem to fail to focus on the unique factors that influence the successful implementation of e-Journals at higher education institutions in Jordan. Hence, this paper is an attempt to study the issues of e-Publication awareness, attitude, perception, and use by faculty members at The University of Jordan, with a view to survey the exposure of academics to e-Publication, in general, and to e-Journals, in particular. Also, it aims to highlight the challenges encountered by the users and suggests some corrective measures for its improvement. Thus, the current study tries to explore the current issues associated with the use of e-Publishing.

A test-retest reliability method of two weeks interval was conducted, response obtained were subjected to Pearson Correlation Coefficient ( $r$ ) method and a reliability co-efficient of (0.89) was obtained. The stratified sampling technique together with a questionnaire was used for data collection on 292 out of a population size of 1199 faculty members, and only 190 responded giving a response rate of (65.1) percent. In addition, fifteen semi-structured interviews were conducted as a qualitative data collection method to investigate users' perceptions and attitudes towards the e-Publishing at the UJ; as well as to gather more in-depth insights on participants' attitudes, perceptions, thoughts, and actions. The data was collected during October and December of 2015.

Descriptive statistics including frequencies, count, and percentages were used in reporting the findings. The study confirmed that $65 \%$ of faculty members indicated that the level of awareness of the use of e-Journals by the academics at UJ is rather moderate. The paper records that the reasons why faculty members at The University of Jordan use electronic journals and publication are: research activity, paper writing for publication, and teaching. It suggests further for an improvement in the access facilities with high Internet speed and subscription to more e-resources by the University Library. Moreover, results indicated that there are several major factors affecting e-Publishing adoption at UJ. Accordingly, this paper highlights the potential challenges facing the implementation of e-Publishing as well as factors that influence e-Publishing implementation and diffusion at higher education institutions in Jordan. The results of this study will benefit the expected audience by identifying what is currently taking place with e-Publishing (e-Journals) experiment at academic institutions in Jordan. 
This study is organized as follows: Section 2 provides a literature review of e-Publishing at an international level. Section 3 discusses the advantages and disadvantages of e-Publishing (e-Journals). Section 4 introduces the e-Publishing at national level; specifically, e-Publishing experiment at The University of Jordan. Section 5 describes the research methodology that was used in the study. Section 6 presents the results and findings of the study. Section 7 provides a discussion related to challenges to the implementation of e-Publishing at UJ. Finally, conclusions, implications, and recommendations are provided in Section 8.

\section{Literature Review}

Several studies on the use of e-Publishing and electronic information resources revealed that attitudes regarding e-Publishing and electronic information resources vary among people [6]. However, Li Liew, Foo and Chennupati [7] argued that while reading an e-Journal is not the same as reading a printed issue, many scholars now acknowledge that electronic documents offer users advanced features and novel forms of functionality beyond those possible in printed form. In addition, a research done by Rajagopal and Chinnasamy [8] on users’ attitudes and approaches towards e-Publishing and e-resources services in Academic Libraries showed that there is a growing interest in e-Publishing and electronic information resources among the academic users at higher education institutions worldwide.

Adoption of e-Publishing and e-resources has made changes in the trend of information behavior of university instructors. In a related study by Brennan, Hurd, Blecic and Weller [9], they centered on how the adoption of e-Publishing and electronic information resources have affected academics' information behavior; the study revealed that academics make fewer visits to the library and read more e-Journals than the print era.

E-Publishing and electronic information resources can assist to enhance and improve several field of study. In this way, Sivathaasan, Achchuthan and Kajananthan [10] focused on a research of demographic variables and usage of e-Publishing and electronic information resources using a sample of (75) university lecturers; they indentified a statistically significant difference between the mean number of usage of e-Publishing and electronic information resources and gender with the highest mean value of male university lecturers.

In another study conducted by Sivathaasan and Velnampy [11], on the use of e-Publishing and electronic information resources and academic performance of university professors, they jointly indicated that usage of e-Publishing and electronic information resources has a strong positive association with academic performance.

Gowda and Shivalingaiah [12] affirmed that the electronic or digital information resources are increasingly becoming available due to application of information and communication technologies (ICT). As a result, the use of electronic resources particularly, the use of back issues of scholarly journals in electronic format is growing more rapidly indicating a shift in user's preferences towards electronic resources.

Herman [13] pointed out that the integration of electronic media into academic work is progressively harnessing the new technologies to scholarly information gathering endeavors and characterizes the information activity of university faculty members in an increasingly electronic environment. So, in this changing information environment, it is necessary to know the researchers' information requirements in different formats to satisfy their needs. In order to understand the preferences towards e-Publishing and electronic resources along with usage patterns, it is important to conduct a research study leading to faculty members covering the research scholars of humanities, sciences, social sciences, and health sciences disciplines who are engaged in research at the University of Jordan.

According to Bar-Ilan, Peritz and Wolman [14], the most active users of e-Journals are the younger members of the teaching and research staff. Whereas, in a related study, Tenopir, King and Bush [15] showed that age was not an influential factor in whether the respondents read articles on paper or in electronic format.

In related study, Azubogu and Madu [16] conducted a survey on the use of computer and Internet technology in teaching and research among the academic staff of Imo State University in Nigeria; they reported a high level of use of information technology by the respondents. They gave reasons for the use of Internet in teaching and research by academic staff to include: ease of use, convenience, free access to the Internet, access to free information on the internet among others.

Oduwole and Akpati [17] carried out a study on the use of e-Journals and electronic information resources at the University of Agriculture Library in Abeokuta, Nigeria. Their study identified lack of ICT and power supply outage as constraints to use of electronic resources and e-Journals. In the same vein, Wattsand Ibegbulam [18] surveyed some of the barriers to the use of e-Journals and electronic information resources available at the 
Medical Library of College of Medicine, University of Nigeria. Their findings exposed that lack of an adequate ICT infrastructure and affordable online access, absence of in-depth ICT skills and information searching skills among library staff, and cost of using the cybercafé are barriers to the use of e-Journals and electronic resources.

Dhingra and Mahajan [19] stated that with a significant growth in ICT, e-Journals are becoming increasingly prevalent in the information landscape of libraries; furthermore, they indicated that the ultimate goal of e-Journals is to provide fast and easy access to the information contained in the objective publications with simple, powerful search, and retrieval capabilities.

E-Journals are often referred to interchangeably as "electronic publishing”, "electronic serials", "online journals" and "electronic periodicals". According to Harrods's Librarians Glossary [20], an e-Journal is a journal which is available in electronic format; a physical printed version may also be available. E-journal, hence, is a term used to describe a journal that is published in digital form to be displayed on a computer screen. The concept of the e-Journal does democratize journal publishing, since anyone with access to a computer equipped with a modem and suitable software can produce and distribute an e-Journal through a computer network.

E-Publishing has been broadly defined as non-print material that is produced digitally. E-Publishing, no matter its form is broadcasted, distributed, or disseminated digitally through a computer. However, an important distinction to note is that not all electronic publications are scholarly. Rather some electronic publications include opinions, views, discussions and other types of information that do not meet the criteria of scholarship. Scholarship in its broadest sense implies that certain criteria have been met: goals are clearly stated, background preparation is sufficient, approach to the issue/topic is appropriate, important conclusions are made; presentation of material is effective, and that the project is thoughtfully evaluated [21].

The reviewed literature indicated that e-Journals are becoming an accepted and necessary means of meeting the demands for the dissemination of knowledge [22]. Simply, an e-Journal is a digital periodical that publishes on the Internet or World Wide Web. An e-Journal may not be all that different from a print journal in the fundamental editorial process. That is, articles are submitted by individuals in the academic and practice community, are peer reviewed by editorial board members of the journal to be accepted or rejected, and subsequently published [23]. Again, as mentioned earlier, even though that there is sometimes confusion between "e-Journals" and "e-Publishing", that is, there is little to differentiate the two terms, but for the purpose of this article they will be considered synonymous.

Tenopir, King, Edwards and Wu [24] reported that e-Journals have produced an advanced method of scholarly interaction in the sense that individuals can respond instantaneously to the articles and these responses can be published as soon as the editors receive them. This creates a more dynamic interaction than in the written journals again highlighting a more simultaneity paradigm than traditional journals allow. While, written journals have always allowed the readers to access knowledge in their own domains without some of the time restrictions of other means information gathering. An individual can carry a written journal from one place to another and read it at will. However, e-Journals allow for a different bending of the time-space concept. For example in the online journal, fluidity of thought and ideas can be seen when the specific issues can continue to be revisited and addressed without regard to the limitations of time that is present in the printed journals. Individuals can add to the body of knowledge of each issue as it changes just by writing a new article or letter to the editor. The advancement of knowledge and historical development of the issue can be chronologically recorded in e-Journals in a way that has never been possible with the constraints of a written journal. The absence of page and space restrictions also adds another dimension to the limited two dimensionality of the printed journal [24].

Lenares [25] has examined the level of faculty use of e-Journals at research institutions. He stated that although many articles have been written in the past fifteen years examining the state of e-Publishing, there has been little empirical research published which examines the levels of use and acceptance of this new format within the scholarly community.

Bashorun, Isah and Adisa [26] examined the user's perception of the electronic resources by the academic staff of the University of Ilorin. Analysis revealed frequency of use of electronic resources was low. However, they outlined a number of obstacles to the use of e-resources such as lack of time because of the time required to focus on teaching; lack of awareness to electronic resources provided by the library; power outage, ineffective communication channels, slow network, and inadequate searching skills.

Radjagopal and Chinnasamy [27] have identified users' attitudes and approaches towards e-resources and examined the perceived advantages and disadvantages of electronic publications. Ultimately, Al-Shboul [28] [29] conducted several studies regarding faculty members' attitudes and perceptions relating to the use of e-Learning 
at The University of Jordan. He also investigated the potential factors related to the use of e-Learning tools by faculty members. Moreover, the findings of these two studies revealed that there are still various obstacles and barriers to overcome in order to have a successful integration of e-Learning into the educational system at this university. Thus, the current research study considered to be continuous efforts by Al-Shboul concerning e-Publishing (e-Journals) at The University of Jordan, which is accordingly related to the use of e-Learning in higher education in general. Furthermore, Al-Shboul and Elyan [30] have discussed the benefits and issued related to e-Publishing, in general, and to e-Book and e-Journals, specifically. They also introduced a comparison between traditional print books (e-Journals) and e-Books (e-Journals).

In summary, the reviewed literature indicated that e-Journals are a new method of delivery of knowledge and building of scholarship. A variety of literature declared that e-Journals represent a paradigm shift. Certainly, a change in thinking has occurred with e-Journals regarding boundaries of knowledge acquisition. In conclusion, the reviewed literature illustrated that e-Journals change the way we educate, focus our practice, share knowledge, and conduct scholarly communication with others in our profession. However, in e-Journals currently we are only changing formats; there is no change in ideas of what scholarship is and what is not. It is a change in method, not thought or worldview, just an evolution of the existing paradigm of scholarship and dissemination of knowledge from traditional methods of publishing to more non-traditional methods. Yet, this change will have to be much broader than current e-Journals to represent a true paradigm shift. E-Journals as currently used and evaluated do not in themselves present new ideas or new ways to structure knowledge that justify a paradigm shift. It is just a rearrangement of how we present information.

In general, e-Journals will be demanded by scholars and researchers in our society and are an economical necessity in today's world. Although e-Journals may only represent a change in delivery method and not a true paradigm shift, they are necessary for current and future research needs. Users are currently accessing information via the Internet as are researchers, theorists, and scholars. It is essential to be computer savvy for researchers to keep in pace in knowledge areas, databases, and communicate with others. Online scholars must be computer savvy in order to access the knowledge and to expand their own learning. We need to continue to look at what this knowledge delivery methodology is capable of in terms of future directions of care and scholarship. Consequently, this study was carried out to examine and perceive how faculty members' use of e-Publications might affect their interest in publishing their own research in electronic formats; as well as to determine the contribution of scholars towards and publishing in e-Journals. Additionally, this research study provides an overview of e-Publishing experiment at The University of Jordan, describes how information increasingly is being exchanged within the scientific community, and discusses the scholarly qualifications of electronic venues.

\section{Advantages and Disadvantages of E-Publishing (E-Journals)}

According to the majority of the reviewed literature [21]-[27], advantages of e-Publishing (e-Journals) include accessibility, usability, increased communication and collaboration between authors and readers, dissemination, technologic capabilities, facilitation of scholarly work, and cost. Whereas, most of the disadvantages of e-Publishing (e-Journals), as stated by the reviewed literature, relate to technical difficulties of the user and network constraints; other disadvantages are user unfriendliness, lack of accessibility, cost, misconduct and security issues, time commitment, and lack of widespread acceptance within the scientific community. In what follows, is an explanation of advantages and disadvantages of e-Publishing; and issues related to print journals as well.

\subsection{Advantages of E-Publishing}

Accessibility: E-Publications (e-Journals) are accessible to all users regardless of geographic location. This accessibility leads to a more diverse audience throughout the world as well as a readership that may include not only academics, but students and lay people.

Usability: Due to the universal accessibility of e-Journals, they can be used regardless of location. The reader is not required to be in a library in a specific place where the specific journal is located. In addition, content from e-Journals can be easily transmitted to others and reproduced. Ease of searchability of content is often cited as an advantage of e-Publication.

Increased Communication and Collaboration between Authors and Readers: The potential for increased collaboration between authors and readers increases as e-Journals move along the continuum from paper content transferred to the Web to fully interactive journals. The electronic medium allows for the opportunity for debate 
and discussion either by posting interchanges between readers and authors, as well as reviewers, related to specific articles, and including datasets that are available to all. The accessibility associated with online journals results in increased diversity and frequency of communication, with a much larger audience than print journals as well as the potential for more interdisciplinary collaboration.

Dissemination: A major advantage of e-Journals is the immediacy of dissemination from review of articles to production and distribution of the articles. Whereas the process from article submission to publication can take at least 1 - 2 years for print journals, the process can take significantly less time for e-Journals. The review process may take 6 - 8 weeks with publication nearly instantaneously once the article is accepted and revised.

Technological Capabilities: Things that are not possible to do with print journals are among the best features of online journals. E-Journals can provide animation, virtual reality, interactive three-dimensional display, forward references, linked comments and replies, and navigational aids such as internal hyperlinks between the text and corresponding tables, figures, and bibliographic references.

Facilitation of Scholarly Work: The greatest facilitator of scholarly work is the ready and quick access to scientific materials, whether they are actual datasets or scholarly articles. The scholar has the most up-to-date information available as compared to print articles which are usually at least $1-2$ years old. The scholar can develop a personal electronic file of articles that is individualized so that materials can be organized and accessed in the manner best suited to the scholar's own needs. The ability to easily track use of e-Journal articles through user sessions or "hits" is a welcome benefit for scholars interested in documenting impact of their scholarly work for promotion and tenure committees.

Cost: Most e-Journals do not charge the reader at the present time, thus the cost for the reader of online journals is less than the cost for print journals. Many libraries have welcomed e-Journals as a way to circumvent the high cost of print journals. There are, however, costs to the publishers of e-Journals in terms of extensive time commitments to produce the journal, use of facilities, and use of materials and equipment.

\subsection{Disadvantages of E-Publishing}

Technical Difficulties: The reader must possess some basic computing and networking skills in order to take advantage of e-Journals. Basic computer skills are needed, in addition to the ability to navigate the World Wide Web. Obviously someone without any computer experience will need help to use e-Journals.

Network Constraints: Users with computer expertise may also find the experience of accessing online journals frustrating. Network constraints and telecommunication problems abound. E-Journals that include graphics often are very slow to access. The lack of technical standardization sometimes results in the inability of the user (reader or researcher) to access sites.

User Friendliness: User friendliness varies widely. Although many online journals contain excellent information, the user unfriendliness of some results in the non-use of the journal. The user (reader or researcher) is required to scroll linearly through the article which may create boredom, eyestrain, or discomfort reading the screen. In addition, the reader who wants to access a back issue may find the task daunting considering the number of steps required and simplicity of following commands highly variable among journals. User friendliness is also limited by lack of consistency and availability of current and accurate information for subscribing to and retrieving e-Journals. Lastly, readers who are used to marking up copies of print articles may miss this print article advantage. However, they are able to print the electronic articles and mark to their hearts content.

Lack of Accessibility: User demographics suggest that there is not equal access to online journals. Findings from several reviewed literature suggest that online journals are less accessible to those outside the United States, females, low income families, and older adults (who did not grow up with computers and must learn computer skills from scratch). Those literature reviews report that those countries accessing journals are those with high connectivity and that there is a low user base in many countries outside of the United States. Low use may also relate to the non-use of English as a second language.

Cost: There are financial and time costs related to the use of e-Journals. The user must have computer requirements: a computer monitor, software, Internet service provider, modem, and browser. Clearly, the financial outlay is prohibitive for many people worldwide.

Misconduct and Security Issues: Although there are misconduct and security issues with print journals, there is a heightened fear of this with e-Journals. Publishers and authors are concerned about falsification of information, piracy, and plagiarism. Electronic publication enables the reader to easily download an article or dataset. 
Consequently, the reader can easily "edit” plagiarize, copy the entire document, or change the actual article, image, or data. Hence, some researchers believe that electronic publication will destroy copyright as we know it.

Time Commitments: The time spent searching for, accessing, and reading e-Journals must be considered. Time commitments for novice computer and network users will be considerable in the beginning. Experienced computer and network users may also spend excessive amounts of time when accessing e-Journals. Although the ability to link to other sources can be quite beneficial, it is not unusual to spend far more time on the computer accessing interesting links.

Lack of Widespread Acceptance within the Scientific Community: The wide variability in quality of articles in e-Journals has resulted in lack of general acceptance of the scientific merit of articles published in online journals. This is due to the fact that only some of the articles are peer reviewed. Some reviewed literature provide a compelling argument that the same peer review standards used in print journals can and should be applied to e-Journals. Although e-Journals are not as widely accepted as print journals as evidence of scholarly productivity at the past time, there has been a significant change at the present with more widespread acceptance of scholarly electronic publications. Table 1 shows a summary of the advantages and disadvantages of e-Publishing.

\subsection{Advantages of Print Journals}

Print journals are advantageous compared to e-Journals, particularly for those with no access to computers and service providers or lacking in the prerequisite skills to search and access electronic publications. Advantages of print journals are user friendliness and acceptance within the scientific community.

User Friendliness: Use of print journals only requires the ability to read and understand the language and no computer skills are required. Since print journals have been the medium that has been used for over five centuries, readers are comfortable with the format and display features including page layout, print quality, text structure, formatting features, table of contents and page numbers. Familiarity with print journals facilitates the ease of reading of the actual article. Of course, the articles can be "marked up" as the reader desires.

Widespread Acceptance within the Scientific Community: Print journals have widespread acceptance within the scientific community as a result of five centuries of established rules of engagement. These rules include standards by which to judge the quality of editorial content, to differentiate author from shill, editorial from advertising, education from promotion, evidence from opinion, science from hype. Print journals have served over time as the mechanism whereby authenticity is guaranteed and work is preserved for the future.

\subsection{Disadvantages of Print Journals}

There are disadvantages associated with print journals including cost, dissemination, user friendliness, lack of communication and collaboration, and lack of facilitation of scholarly work.

Cost: The costs of print journals have been rising exponentially. Subscription costs to individuals and libraries are soaring as paper, ink, and mailing expenses have risen. Individual scholars with limited financial resources and limited access to libraries may not be able to access relevant print journals. The cost of maintaining journal

\begin{tabular}{cc} 
Table 1. Advantages and disadvantages of e-Publishing. \\
\hline E-Publishing Advantages & E-Publishing Disadvantages \\
\hline Accessibility & Technical Difficulties \\
Usability & Network Constraints \\
Communication and Collaboration & User Friendliness \\
Dissemination & Lack of Accessibility \\
Technological Capabilities & Cost \\
Facilitation of Scholarly Work & Misconduct and Security Issues \\
Cost & Time Commitments \\
& Acceptance Issues
\end{tabular}


collections and archiving past collections is significant. Although not cited frequently as a disadvantage of print journals, the proliferation of paper is environmentally destructive.

Dissemination: The process from print article submission, to review of articles, to production and dissemination of the articles is slow. This has major implications for the inability of readers to have up to date information.

User Friendliness: Although print journals are usually user friendly, for those who do not use English as a first or second language, print articles may be incomprehensible. Translation into the reader's native tongue requires obtaining a hardcopy of the article and translation services. This is much more difficult to accomplish than using translation software that is sometimes available for online publications.

Lack of Communication and Collaboration: Communication within print journals is usually limited to "letters to the editor" and is a onetime response. The space requirements of print journals also limit continuing dialog. Print journals offer far less opportunity for communication and collaboration than e-Journals. Letters to the editor appear months after the initial article was presented and readers may not have easy access to the article that is discussed in the letter.

Lack of Facilitation of Scholarly Work: One of the most important criteria for assessing the impact of scholarly work in academia is the number and sources of citations to one's scientific work. The scholar is able to ascertain other scholars' use of their work through their publications via standard indexing sources. However, it is impossible to document the readership of specific print journal articles. This contrasts with e-Journal articles where number of readers of specific articles, as well as amount of time spent reading the articles, can be identified.

\section{E-Publishing Experiment at the University of Jordan}

The University of Jordan, since its establishment on 1962, has realized the importance of research and its role in the development of nations. As part of the philosophy and mission of pursuing distinction amongst its activities in establishing a cultural passion for research and discovery and in supporting, promoting its tools, the University of Jordan has entrusted special diligence to scientific research and founded in the year 1973, the Deanship of Academic Research [31].

The deanship is responsible for organizing, supervising, promoting, and supporting academic research as the means for vast development and technological advancement. The role that the Deanship of Academic Research is playing in augmenting and expanding human knowledge is recognized through persistently seeking ways and new endeavors to encourage, develop, promote and support scientific activities both locally and internationally. The deanship has largely concentrated and carefully considered modernizing and developing its tools to include interdisciplinary research with emphasis on integrated and comprehensive tracks in all disciplines. The deanship aims at achieving the university's objective of helping faculty members at the university to push their research to internationally recognized levels and to promote scientific knowledge. The deanship provides researchers with whatever they need, from the latest equipment, to programs that help them accomplish their research proposals in the best possible manner. The Deanship of Academic Research has the following duties and responsibilities:

1. Funding research projects conducted by faculty members and other university personnel.

2. Publishing original research proposals, studies, books, translations, and manuscripts.

3. Issuing "Dirasat", a refereed set of journals published in seven different fields: Administrative Sciences, Agricultural Sciences, Educational Sciences, Engineering Sciences, Human and Social Sciences, Pure Sciences, Sharia, and Law Sciences.

4. Issuing the following refereed journals in cooperation with the "Ministry of Higher Education and Scientific Research": Jordan Journal for Agricultural Sciences, Jordan Journal for Business Administration, Jordan Journal for History and Archaeology, Jordan Journal for Pharmaceutical Sciences, Jordan Journal for Social Sciences, and Jordan Medical Journal.

As mentioned above, the Deanship of Academic Research at University of Jordan published seven specialized series of Dirasat, which is an international peer-refereed research journal. Issues of Dirasat: Educational Sciences, Administrative Sciences, Engineering Sciences, and Pure Sciences are published bi-annually. Articles submitted are reviewed according to the highest standards by scientists specialized in their fields. The articles are written either in Arabic or in English.

E-Publishing at The University of Jordan, is a new experiment, started about three and a half years ago (Janu- 
ary 2013); but already most journals issued by the Deanship of Academic Research are published in electronic as well as print versions. Some are published in electronic form only. According to the mission statement of the Deanship of Academic Research, the availability of journals online has created the possibility of an easy and cheaper (sometimes even free) access to the scientific data. The scientific literature needed "evolution", and its evolving tools are: e-Publication, open access, and open peer review. Online publication not only frees journals of print page constraints but also enables them to publish more articles (for instance, online-only) at a fraction of what is used to cost to publish in print.

E-Publishing in Dirasat journals provides several advantages; from the journals' perspective, the Internet means it is possible to reach new readers and new papers around the world more easily and cheaply than ever before. Although many journals maintain a national or regional focus, many others are seeking to internationalize their content and obtain a world audience. All this means that everyone has a place to publish, and these places have become easier to find. Another advantage is speed of publication; manuscript submission to Dirasat journals and peer review processes via the Internet are faster than the paper-based alternatives. It is not just a matter of electronic communication being faster than post (although that in itself can save weeks for an international submission); there also seems to be immediacy about electronic communications that encourages editors, reviewers, and authors to respond more promptly.

As mentioned earlier, Dirasat journals are adopting Internet based manuscript submission and peer review; thus, e-Publishing systems of Dirasat journals provide immediate confirmation of receipt of submission and Web-based manuscript tracking that is accessible by the author/researcher, reviewer, and journals' editors. In addition, some refereed journals issued by the Deanship of Academic Research have more open, peer review procedures. This speeds things up by helping move articles to reviewers more quickly. However, the limiting step will still be the time it takes someone to make a thorough analysis of the submitted work. Some of the Dirasat journals are conducting a more open dialogue between the authors/researchers, the reviewers, and the editors. But, for the next years, the online journals will still continue with anonymous peer-review, and this system can be successfully extended to deal with the complexity of online information.

Another one of the advantages of e-Publishing in Dirasat journals is the accessibility. The ability to locate relevant scientific results quickly will dramatically accelerate scientific progress and, consequently, improve research quality. Indeed, what is read in Dirasat journals is determined primarily by ease of access. Although it has been long argued that papers freely available in a journal will be more often read and cited than those behind a subscription barrier, solid evidence to support such a claim has been hard to find.

On the other hand, free access to content comes with a financial cost to the publishers, through a potential loss of subscriptions. A survey of authors/researchers [32] conducted in April, 2014 at The University of Jordan showed that authors/researchers valued the free access to research articles and considered this an important factor in deciding whether to submit to the e-Publishing system adopted by Dirasat journals. Closing access to research articles would have a negative impact on authors' perceptions of the journal and their likeness to submit. When getting rid of print journals in favour of e-Publication, the most substantial barriers are economic.

In short, e-Publishing is the central technology of the scientific-academic literature. Researchers and scholars are approaching a globalized academic literature, in which it will be increasingly easy to move from article to article, journal to journal, without interruption. How this will be paid remains uncertain. For the time being, the Dirasat journals can neither afford to lose subscribers, nor charge authors for publishing their papers. Whatever financing system is adopted, the transition to online publishing at The University of Jordan is now in place, and this gives Dirasat journals published electronically by the Deanship of Academic Research greater potential to obtain the attention and respect of a broader audience.

\subsection{Guidelines for Authors for Using the Online Journal Submission System at UJ}

This part of the article will describe the steps that authors or researchers need to follow in order to use the Online Journal Submission system (OJS); that is, e-Publishing system at The University of Jordan. The figures below demonstrate procedures and present detailed explanations for authors, as "Users Manual", when submitting a paper to e-Publishing system adopted by Dirasat journals issued by the Deanship of Academic Research at The University of Jordan.

1. Go to the Deanship of Academic Research's Website: http://research.ju.edu.jo/, as shown in Figure 1. Select the journal in which you want to publish (Dirasator Jordan Journals). Assume you want to submit a paper to the Dirasat Journal: Educational Sciences. 


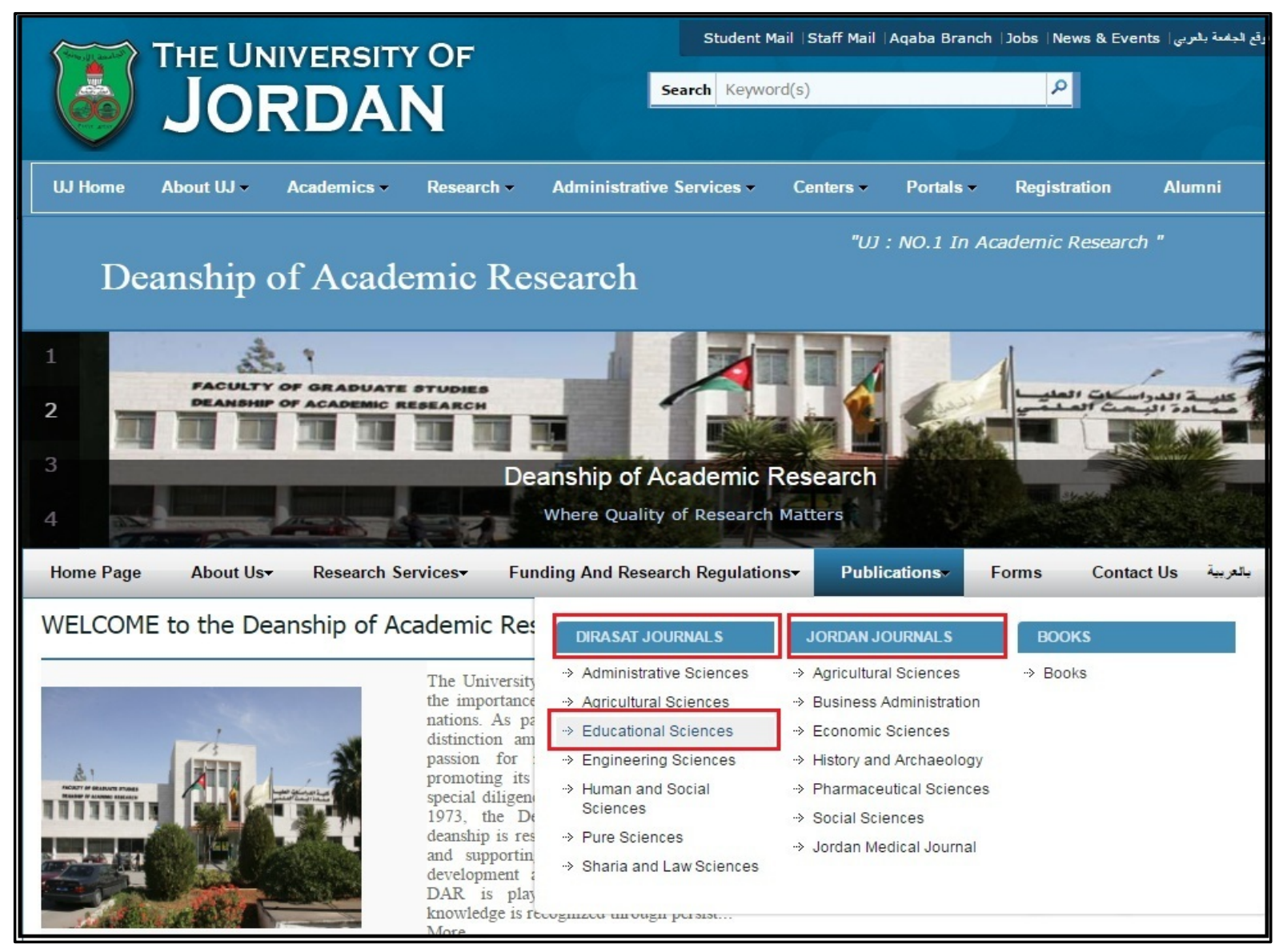

Figure 1. The deanship of academic research website.

2. If this is your first time using this system, click on the "REGISTER" tab to register via the system, as shown in Figure 2. If you already registered click "login" link.

3. Fill the form. Then press the "Register" button. Enter the username and password you would like to use to login to the system, as shown in Figure 3.

4. Click on "New Submission" to start the submission process, as shown in Figure 4.

5. Step One: You must confirm each item in the submission checklist is correct and tick each box. Press "Save and continue", as shown in Figure 5.

6. Step Two: [a] Click "Browse" to select your article file. [b] You must click "Upload" to upload the file to the systems. Then click "Save and continue". The file should be in Microsoft Word, RTF or WordPerfect document file format, as shown in Figure 6.

7. Step Three: Complete the authors' details. All fields marked with an asterisk $\left(^{*}\right)$ are required. Note: If there are multiple authors, use "Add Author" button to bring up additional fields, as shown in Figure 7.

8. Step Four: If you have Supplementary Files (instruments, data sets, figures or tables) in any file format: [a] Click "Browse" to select your file. [b] You must click "Upload" to upload the file to the system, as shown in Figure 8. [c] Complete the necessary information about the supplementary file as shown in Figure 9. If you don't have any supplementary files, click on "Save and continue" to skip this step.

9. Step Five: you must confirm the submission by click "Finish Submission", as shown in Figure 10.

10. Now, the status of your article should be "Awaiting Assignment", as shown in Figure 11, and you will receive a confirmation email.

11. How to follow up your submitted article? [a] Click on the article title as shown in Figure 11. [b] Click on "Review" tab as shown in Figure 12. In case the reviewer asks for modifications, you can download them as shown in Figure $12\left(^{*}\right)$. Then, you can upload the modified article as show in Figure $12\left(^{* *}\right)$. 


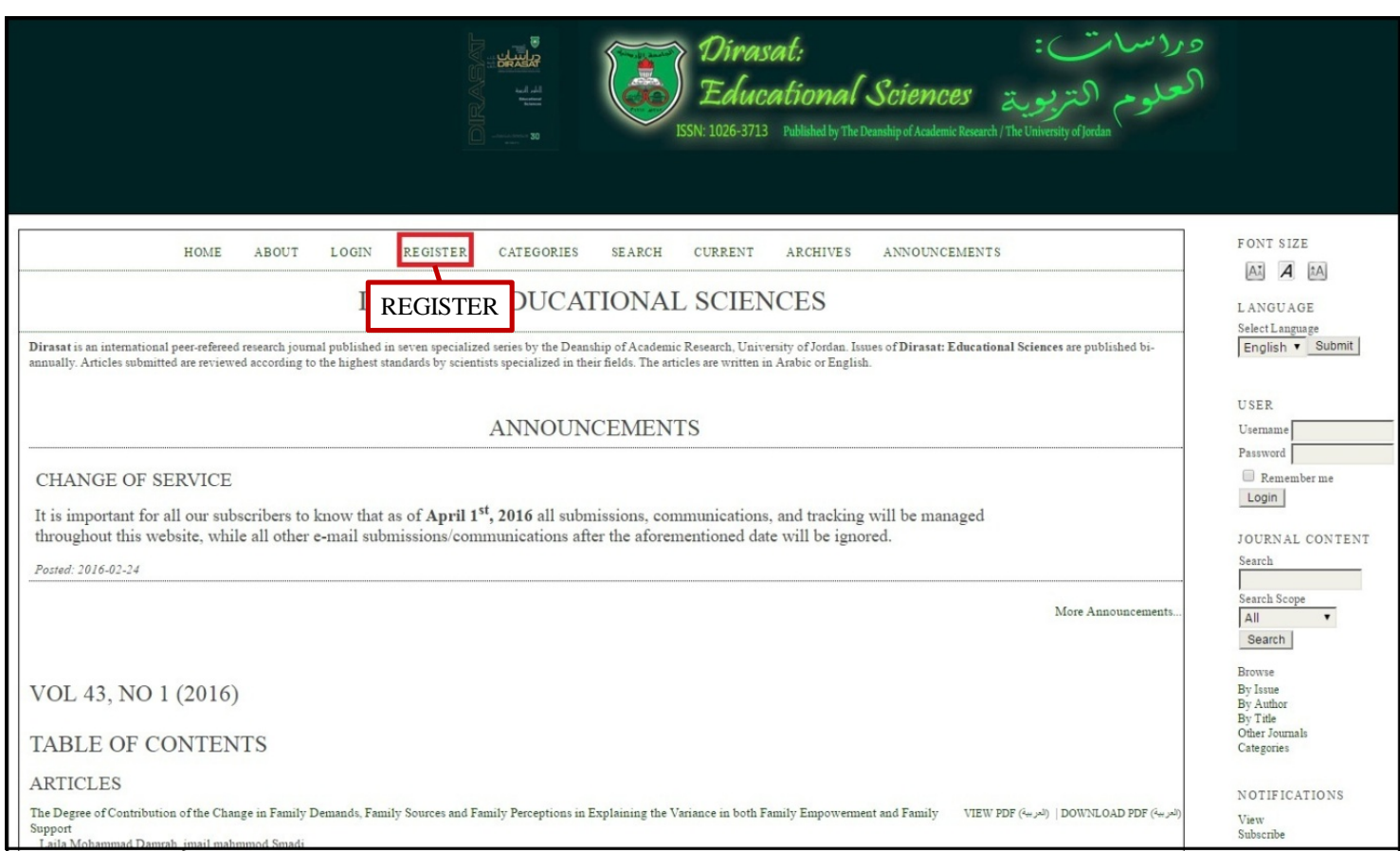

Figure 2. The online journal submission webpage.

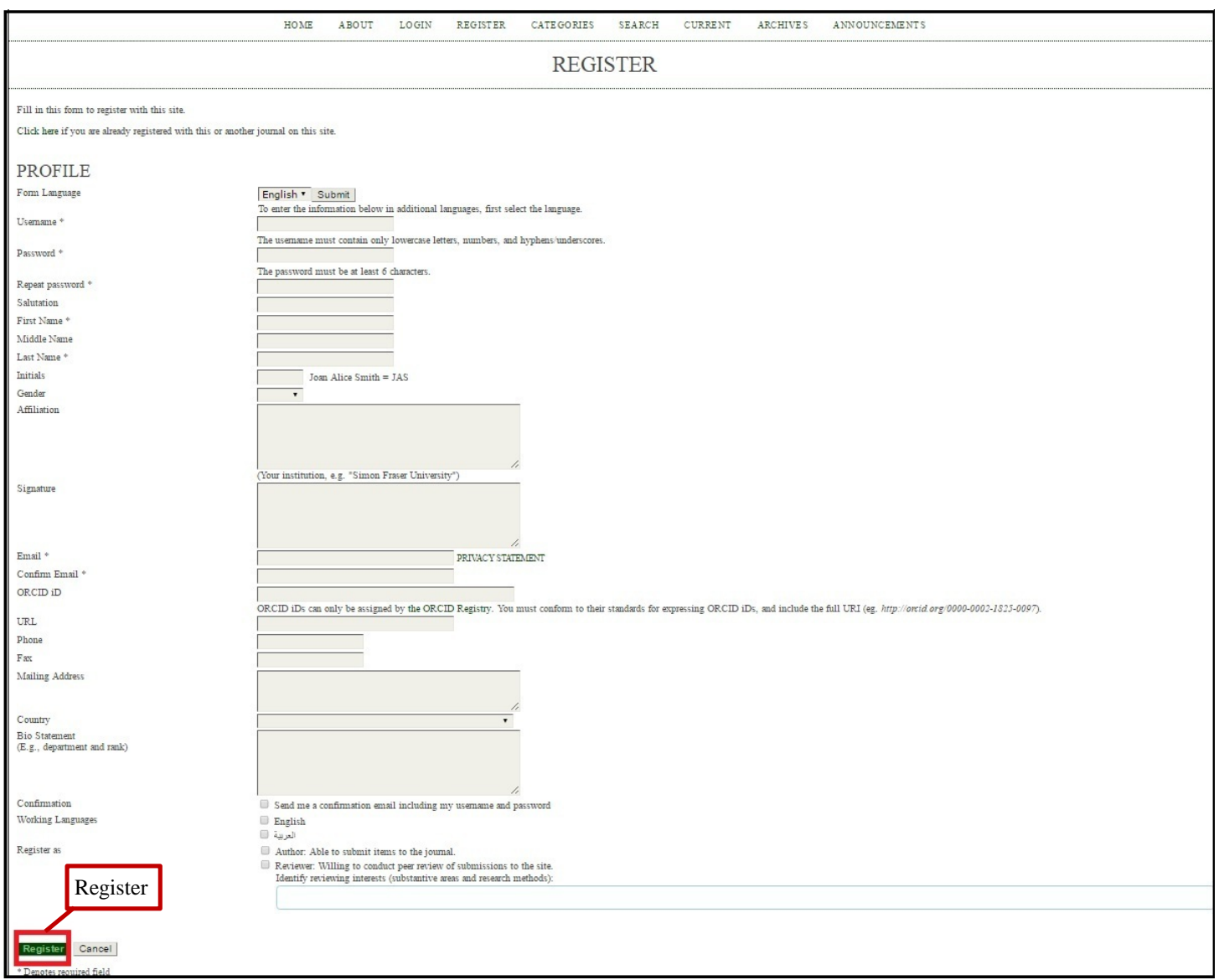

Figure 3. Registration page. 


\begin{tabular}{|l}
\hline \multicolumn{1}{|c|}{ HOME } \\
\hline
\end{tabular}

Figure 4. User home page.

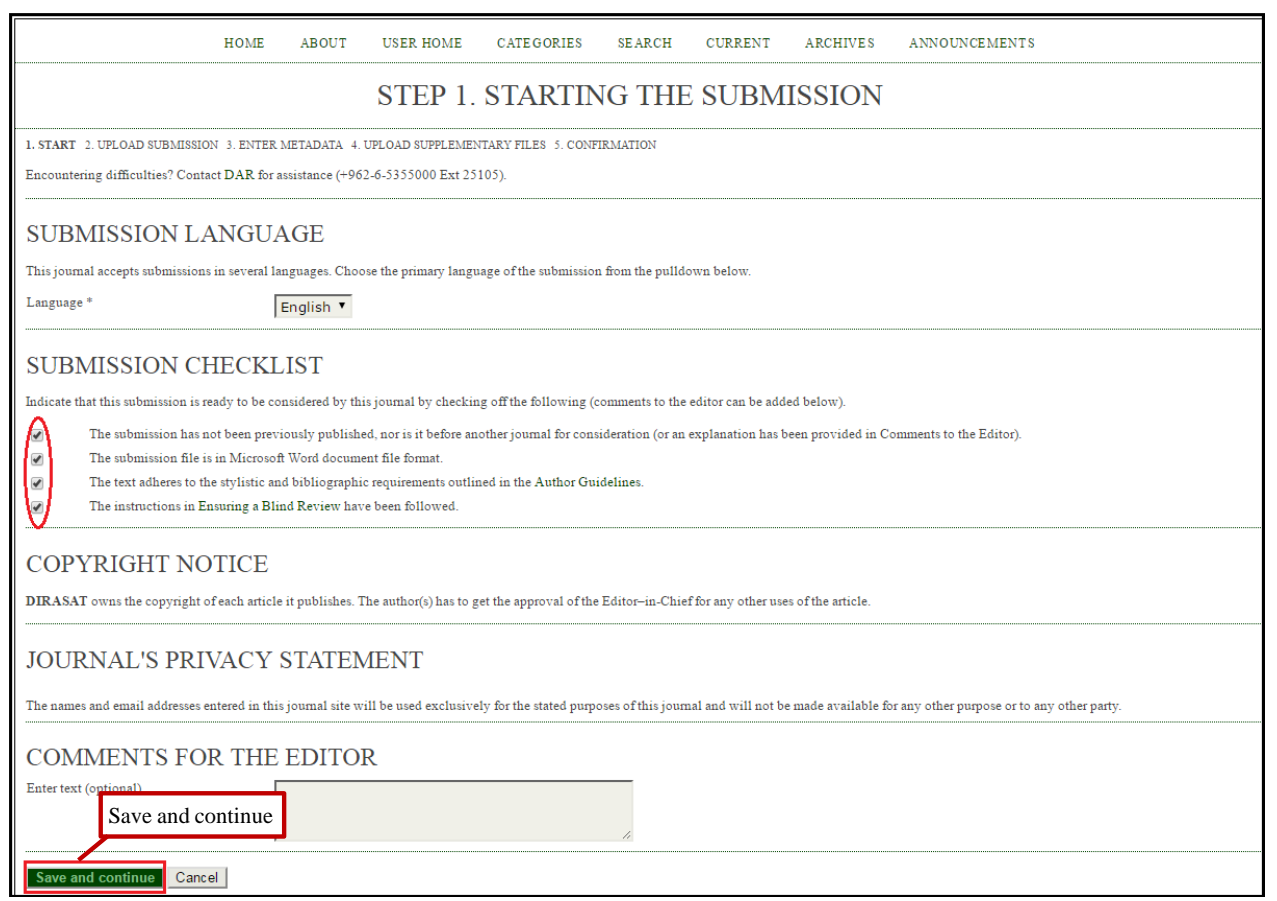

Figure 5. First step in the submission process.

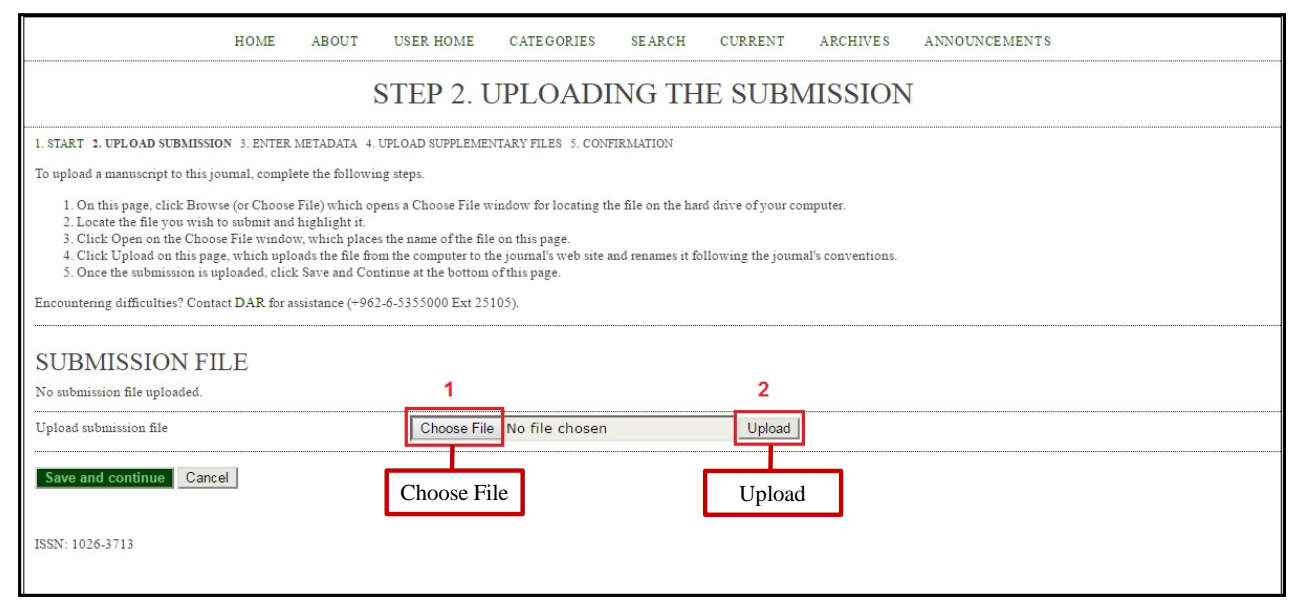

Figure 6. Uploading the article. 


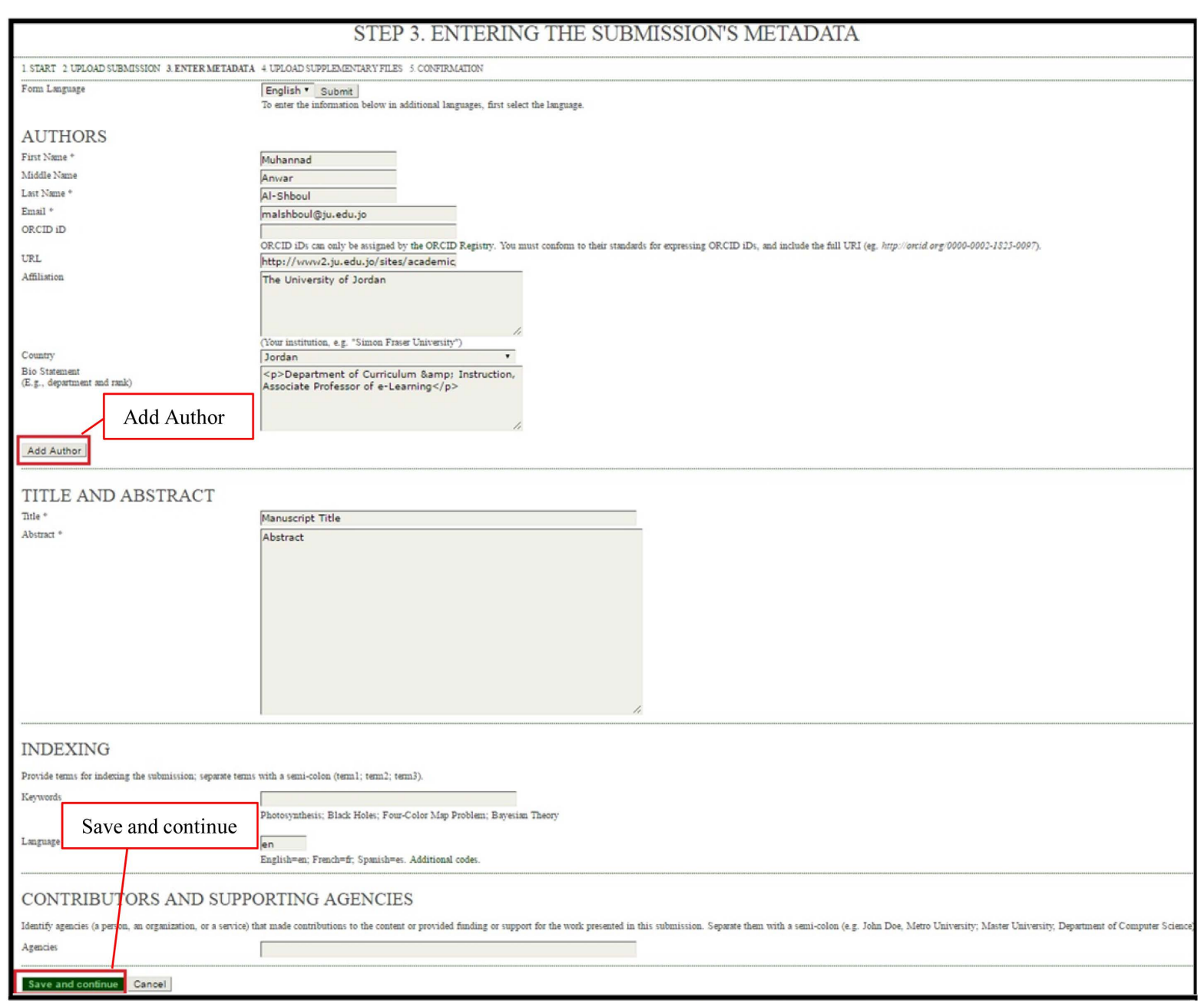

Figure 7. Entering submission metadata.

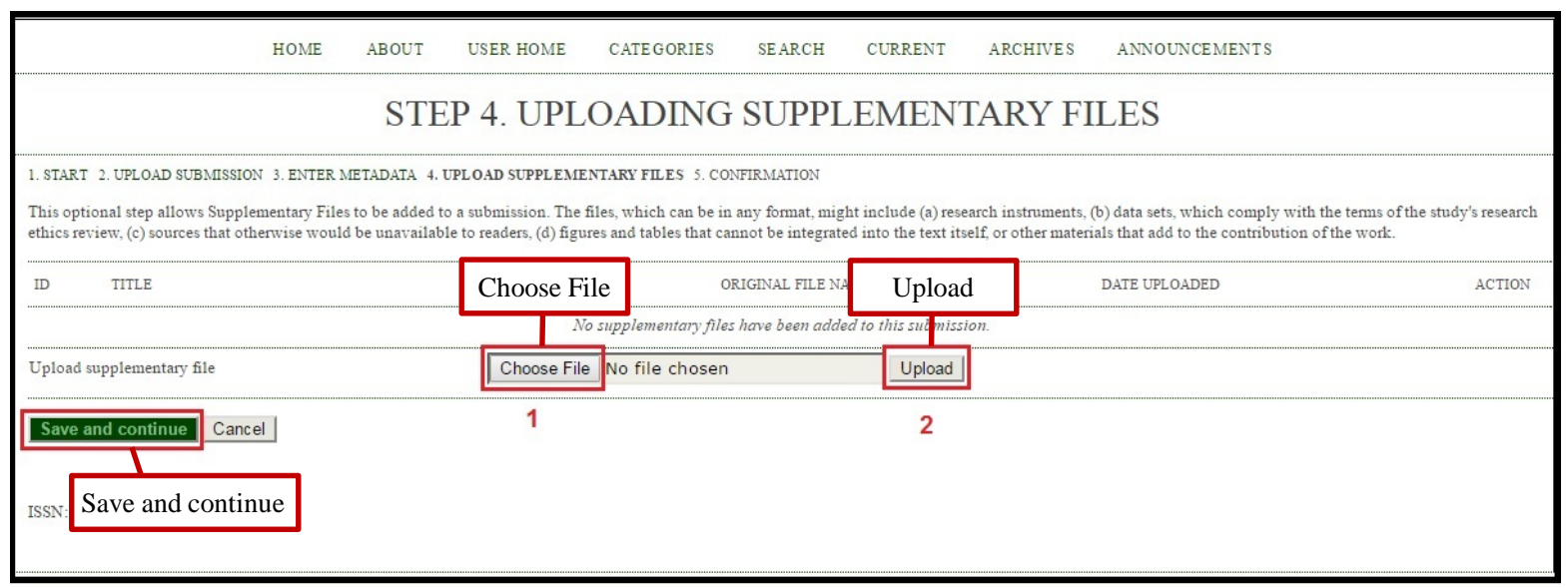

Figure 8. Upload supplementary files.

\subsection{Guidelines for Reviewers for Using the Online Journal Submission System at UJ}

This part of the article will describe the steps that reviewers need to follow in order to use the Online Journal Submission system (OJS); that is, e-Publishing system at The University of Jordan. The figures bellow present 
STEP 4A. ADD A SUPPLEMENTARY FILE
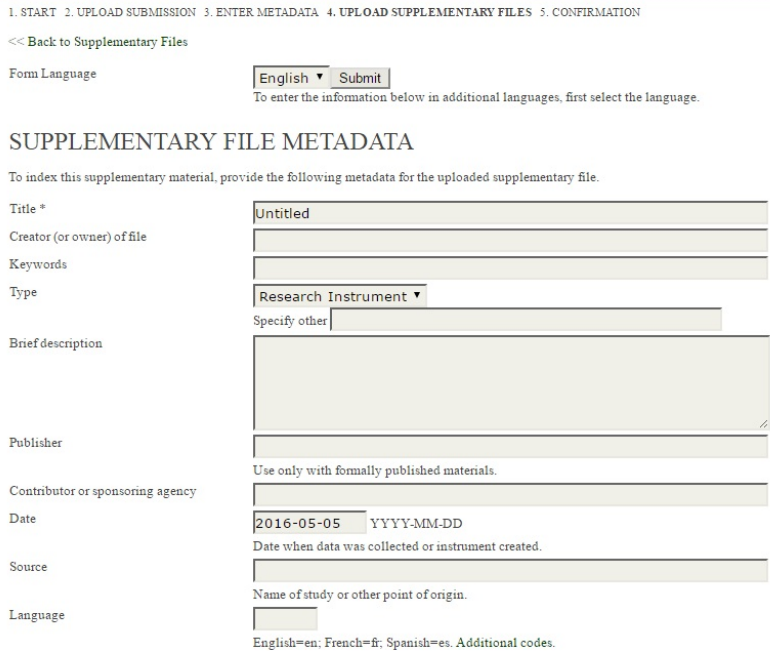

SUPPLEMENTARY FILE

No file uploaded.

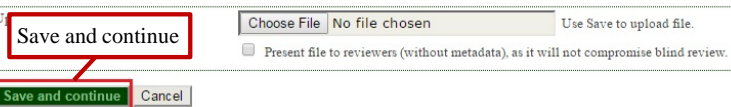

Figure 9. Supplementary file metadata.

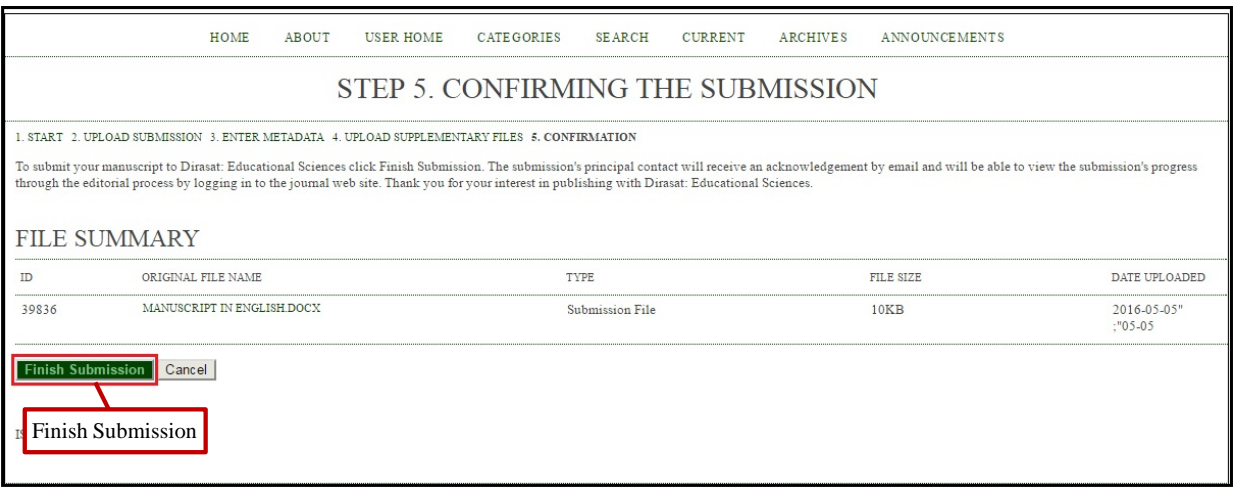

Figure 10. Finish submission.

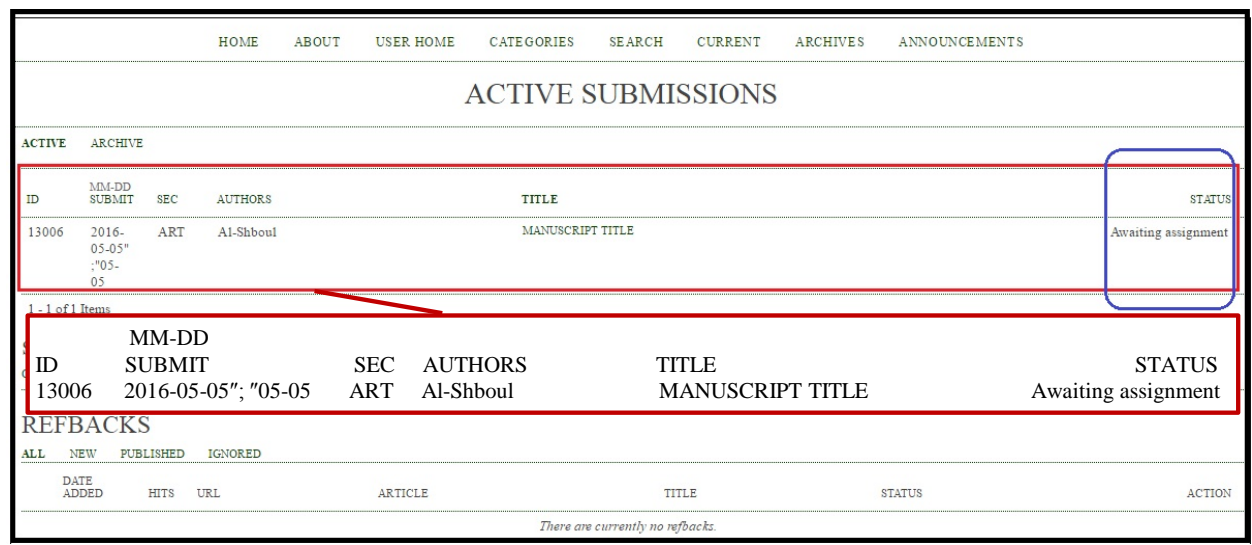

Figure 11. Active submissions. 


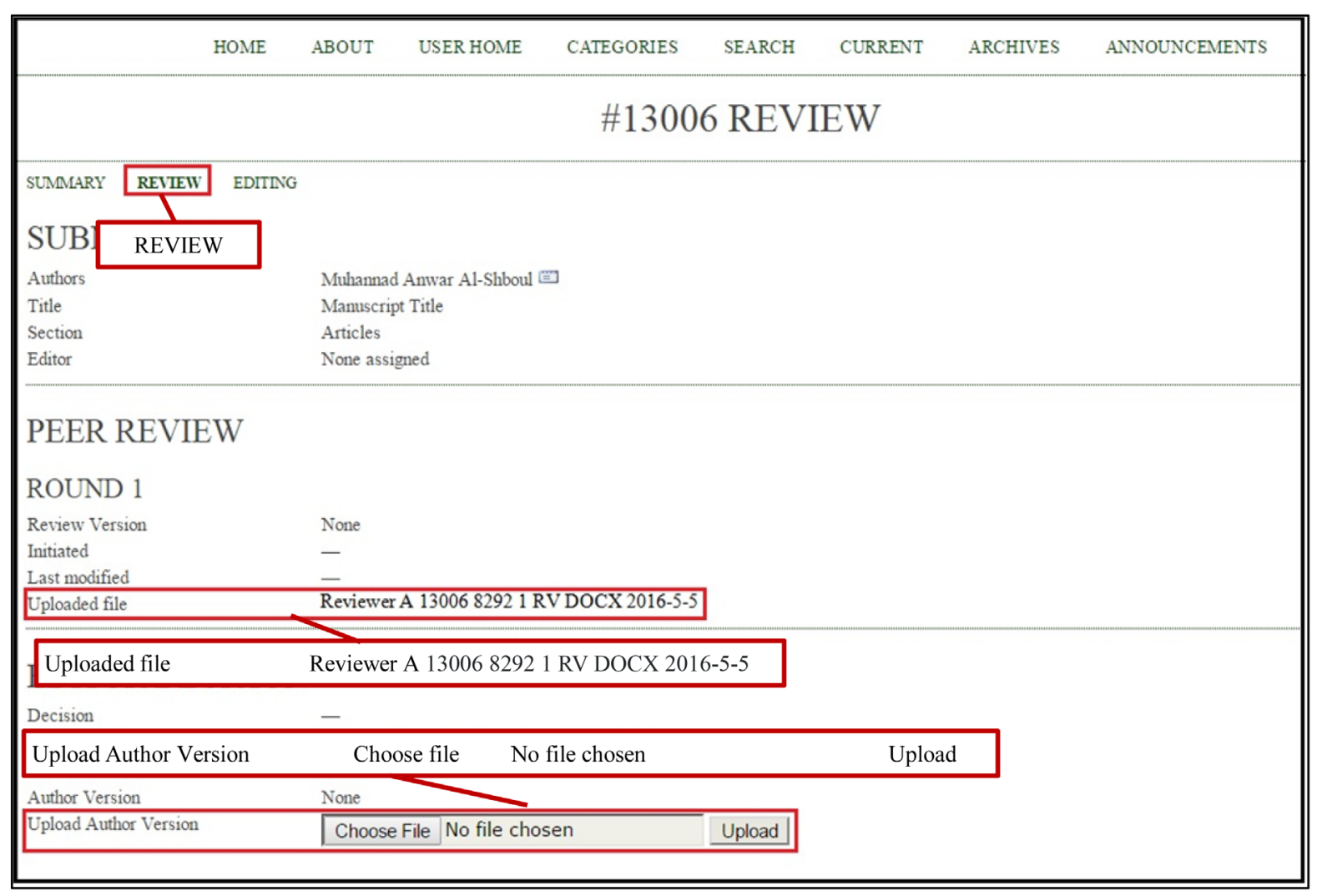

Figure 12. Upload the article with the required modifications.

detailed explanations and procedures for reviewers as a Manual for the Dirasat Journals Portal (Reviewer)"when reviewing an article submitted by researchers to e-Publishing system adopted by the Deanship of Academic Research at The University of Jordan. The following figures illustrate the steps needed to review a research in the Dirasat journals e-Publishing system.

1. Log in to the journals portal: http://journals.ju.edu.jo and choose the journal containing the research you want to review, as shown in Figure 13. For example, Dirasat Journal: Administrative Sciences.

2. Click on the Reviewer's “Active” researches, as shown in Figure $\mathbf{1 4 .}$

3. Click on the title of the research you want to review, as shown in Figure 15.

4. Please review the research's title and abstract. And then follow the reviewing steps as shown in Figure $\mathbf{1 6 .}$

5. Step One: [a] If you accept to review a research, click on “Accept” or on "Response” in case you were not capable of reviewing this research, as shown in Figure 17.

6. Step One: [b] In case you accept to review a research, a "Send an Email" screen appears. Click on "Send" to confirm your acceptance in reviewing a research, as shown in Figure 18.

7. Step Two: Click on the files link to upload the research and its associated files, as shown in Figure 19.

8. Step Three: Click on the "blue icon" to fill up the review form, as shown in Figure 20.

9. The review form must be filled and then click on "Save", as shown in Figure 21. You will be redirected to the page containing the reviewing steps, if the form was filled correctly.

10. Step Four: This step is optional. If modifications are required, you can attach a file to the author, by choosing the file, then by clicking on “Upload”, as shown in Figure 22. Note: The reviewer's name must not be mentioned in the report.

11. Step Five: A recommendation must be chosen in order to complete the reviewing process, and then click on "Submit Review To Editor", as shown in Figure 23. Note: Once you have chosen the recommendation, and have clicked on "Submit", then you have finished reviewing and you cannot attach or modify anything.

12. After you finish reviewing and sending your final recommendation, the file is sent to the "Archive" list as shown in Figure 24. 


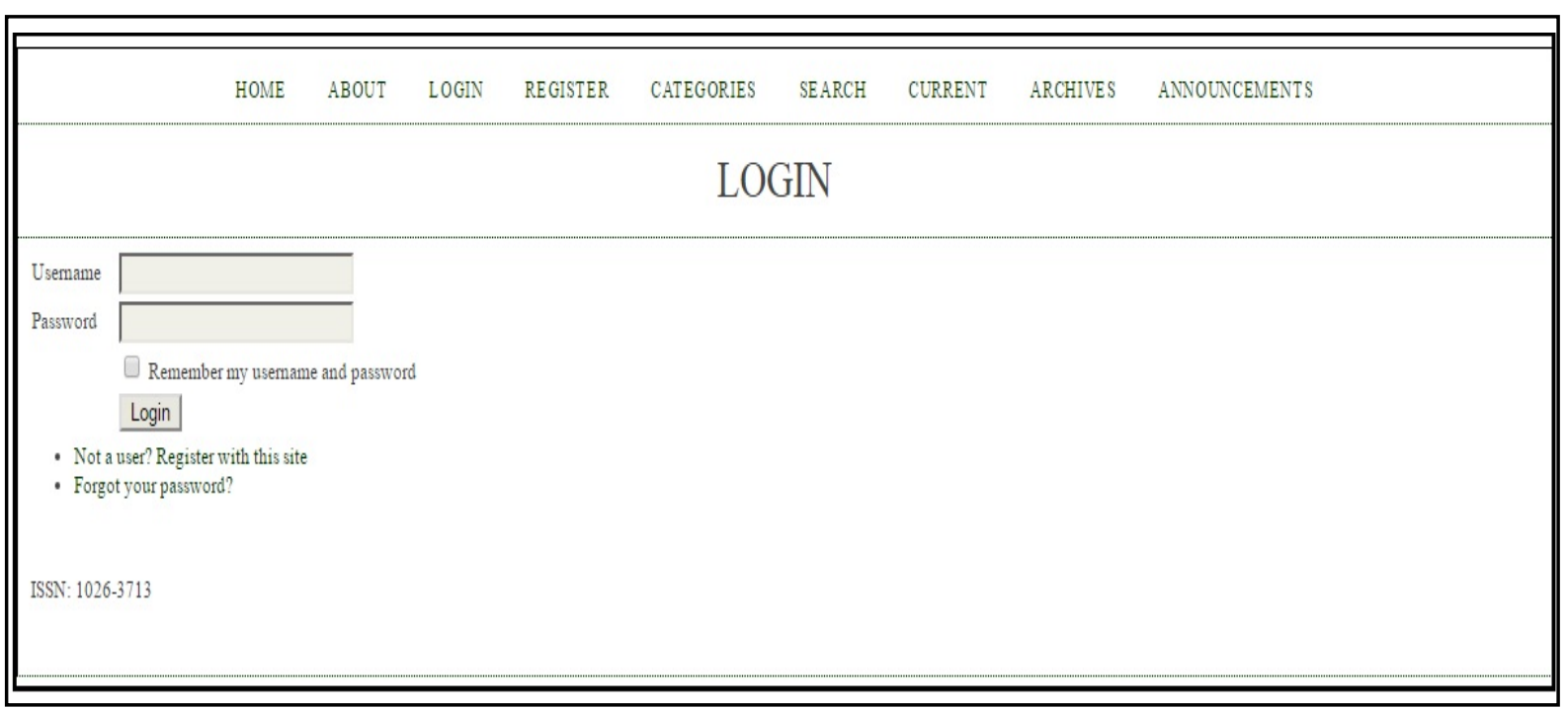

Figure 13. Reviewer log in page.

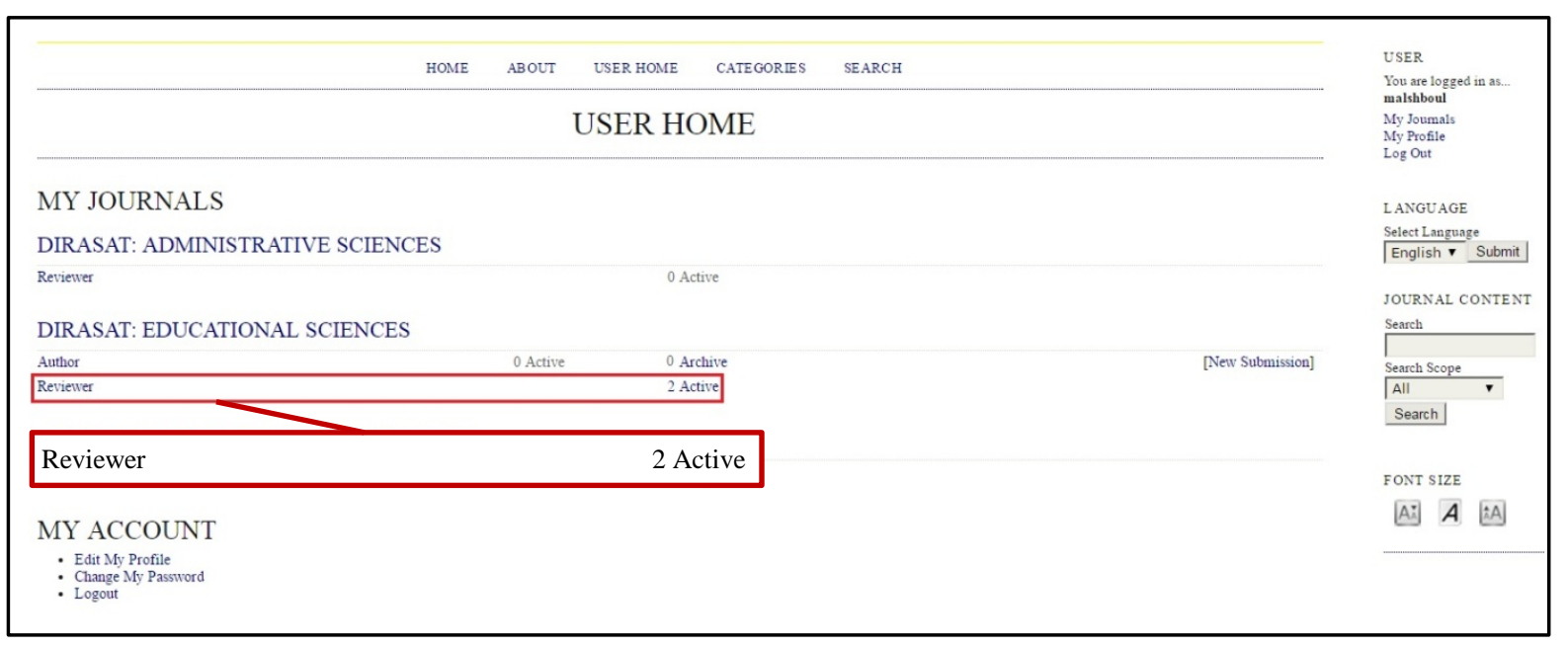

Figure 14. Reviewer/user home page.

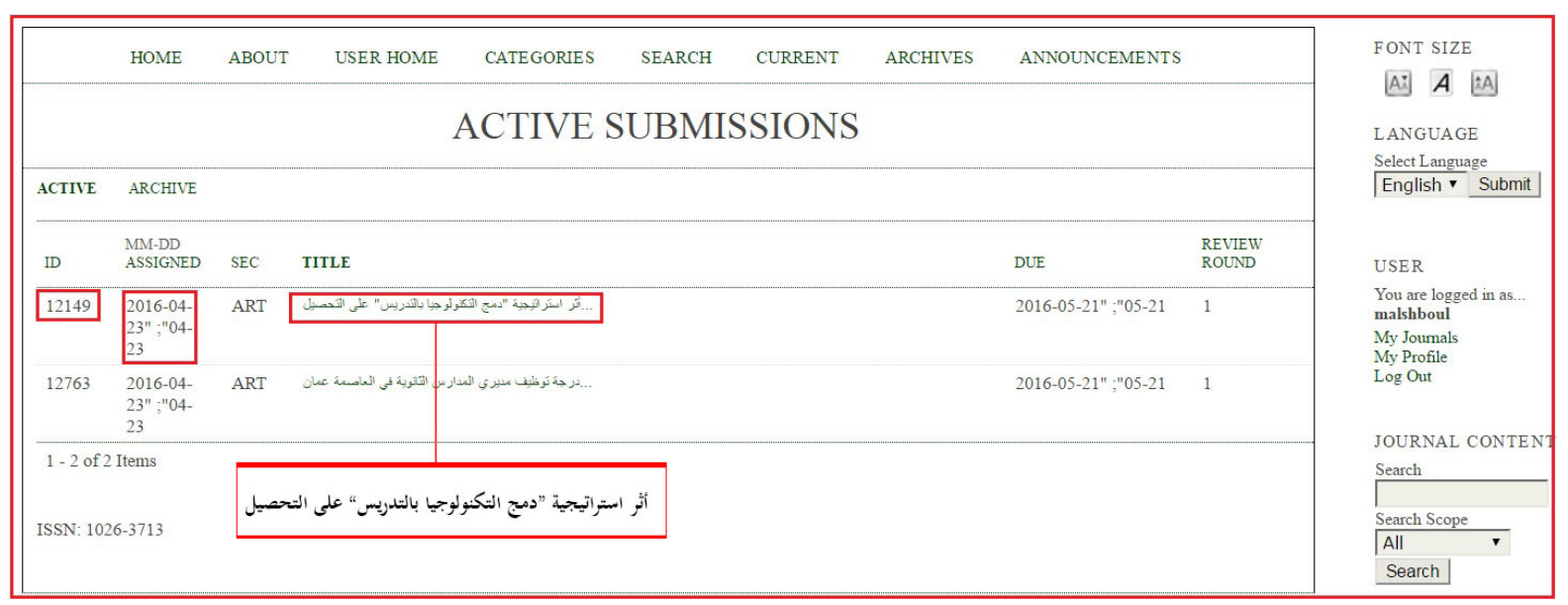

Figure 15. Active submissions. 


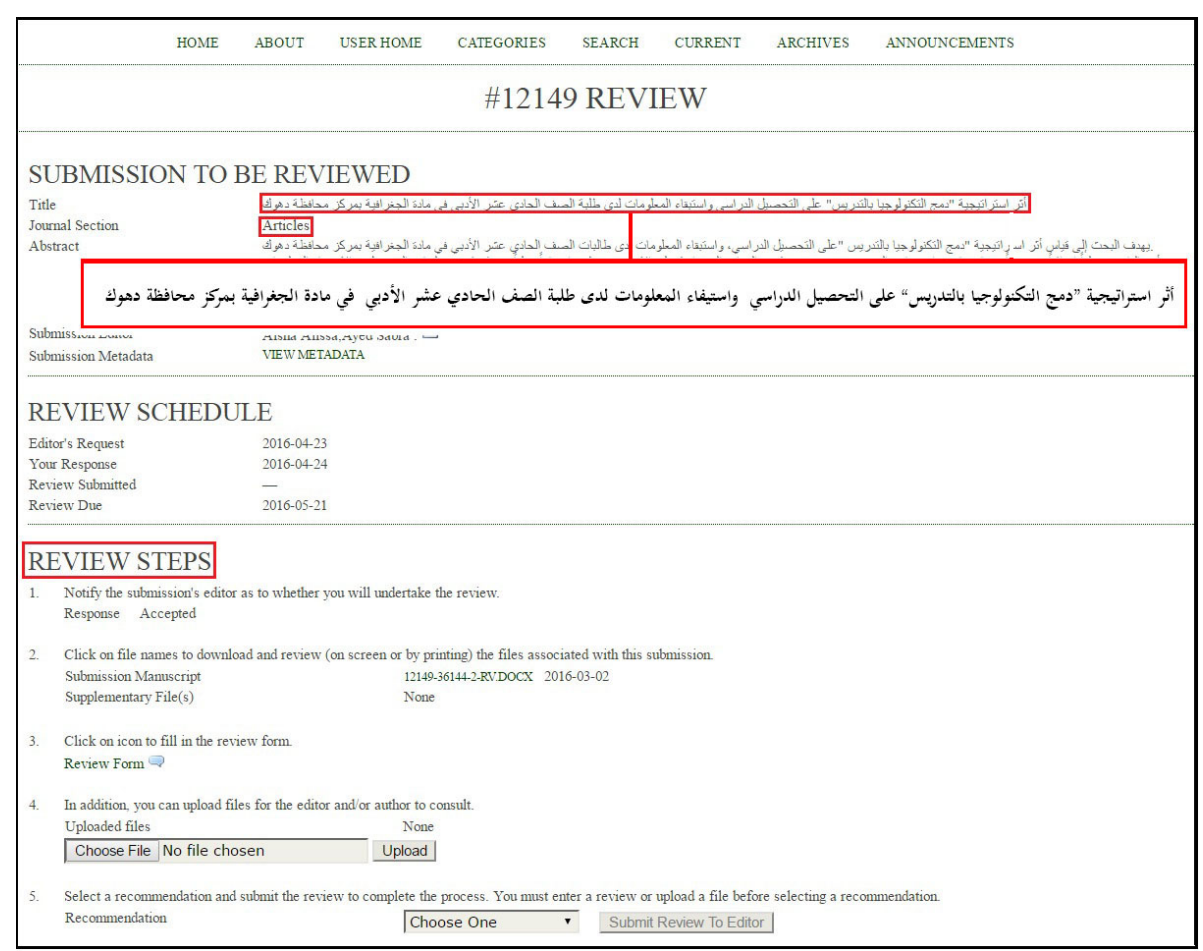

Figure 16. Reviewing steps.

\section{REVIEW STEPS}

1. Notify the submission's editor as to whether you will undertake the review.
Response Accepted

Figure 17. Accepting or rejecting the review.

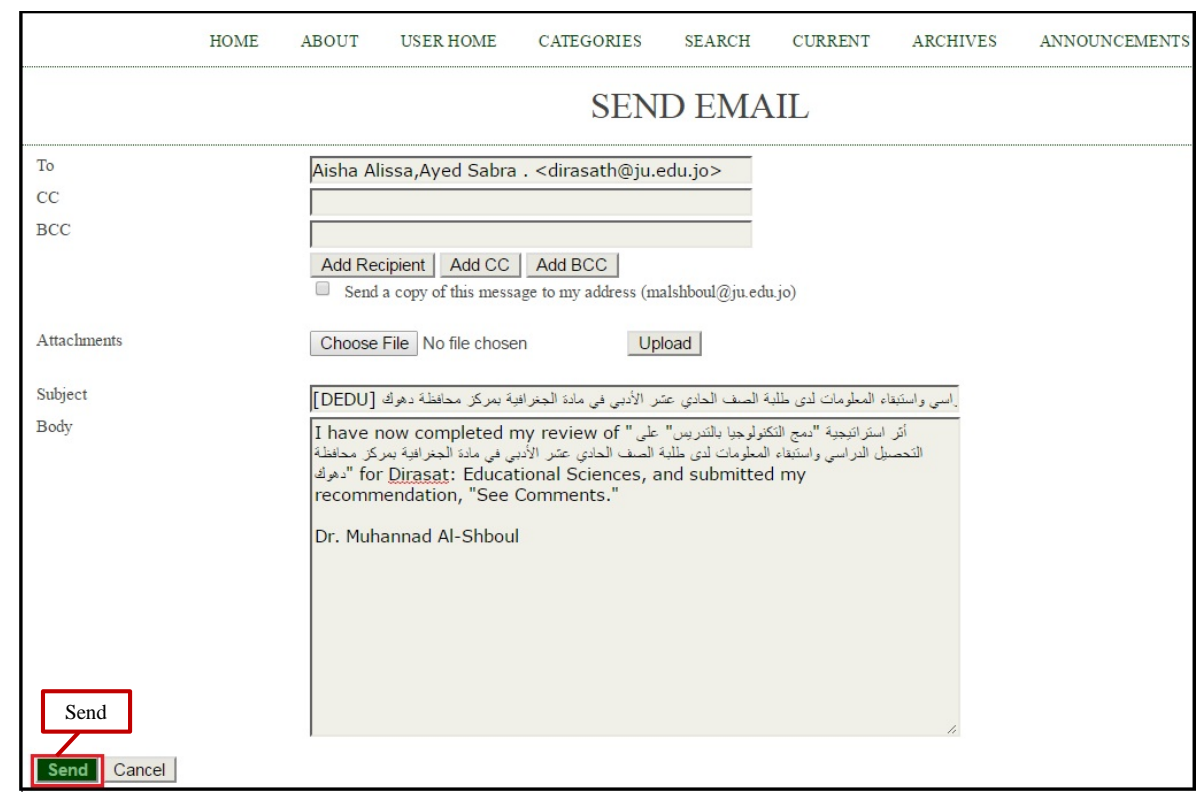

Figure 18. Sending an email. 
2. Click on file names to download and review (on screen or by printing) the files associated with this submission. Submission Manuscript 12149-36144-2-RV.DOCX 2016-03-02 Supplementary File(s) None

Figure 19. Uploading the files.

$$
\begin{aligned}
& \text { 3. Click on icon to fill in the review form. } \\
& \text { Review Form }
\end{aligned}
$$

Figure 20. Uploading the files.

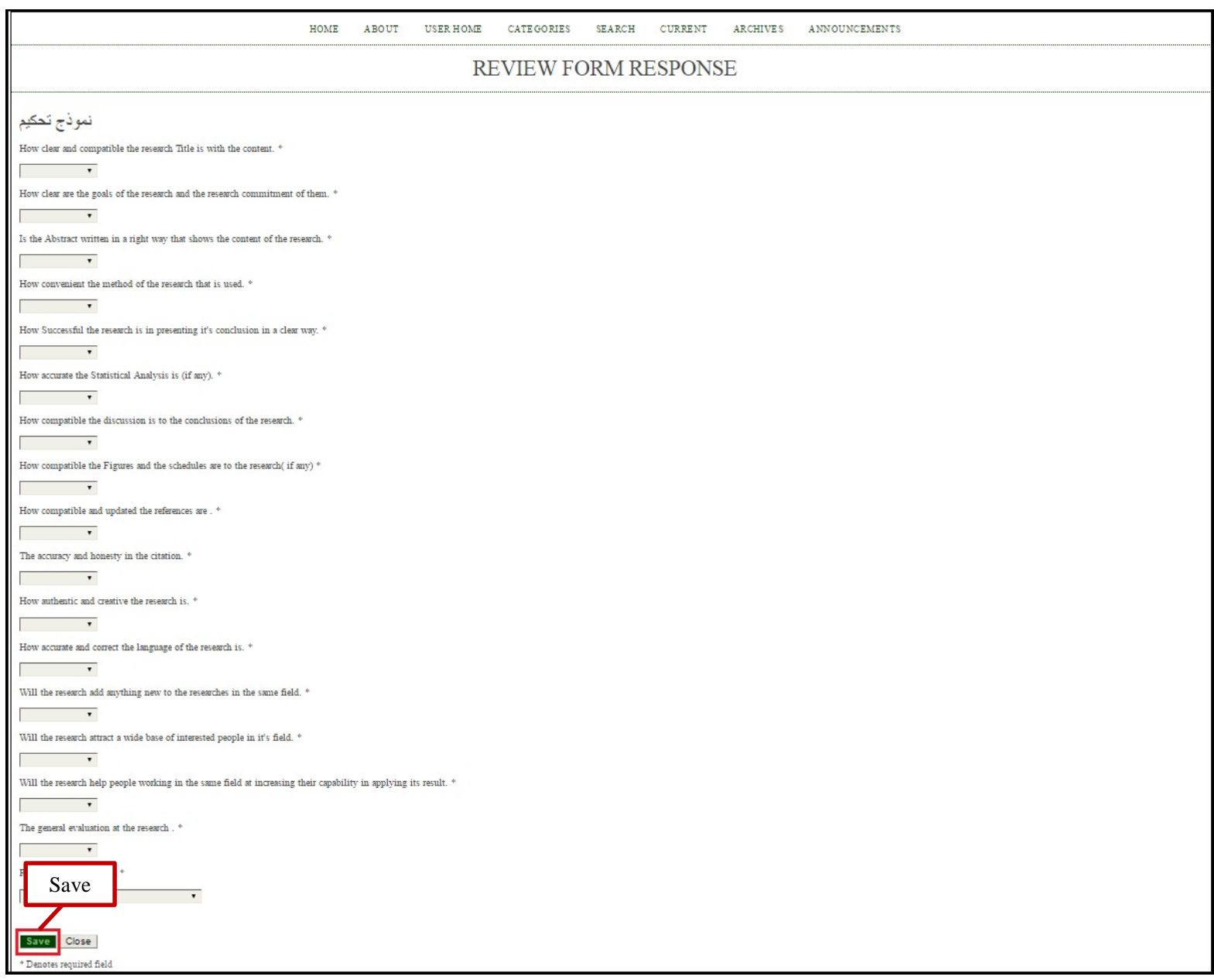

Figure 21. The review form.

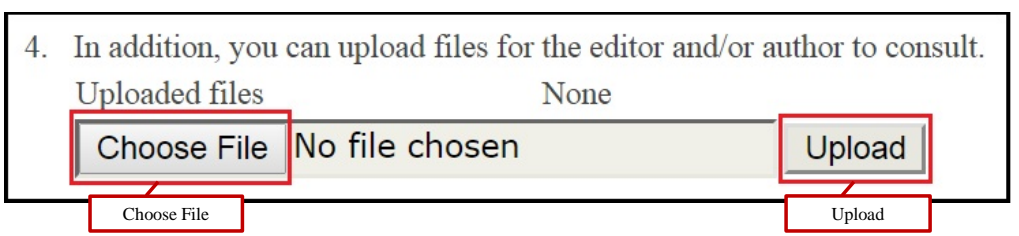

Figure 22. Uploading files (modifications report) for the author. 
5. Select a recommendation and submit the review to complete the process. You must enter a review or upload a file before selecting a recommendation.

Recommendation

\begin{tabular}{|l|}
\hline Choose One \\
Accept Submission \\
Revisions Required \\
Resubmit for Review \\
Resubmit Elsewhere \\
Decline Submission \\
See Comments \\
\hline Choose One \\
\hline
\end{tabular}

Submit Review To Editor

Submit Review To Editor

Figure 23. Selecting recommendation.

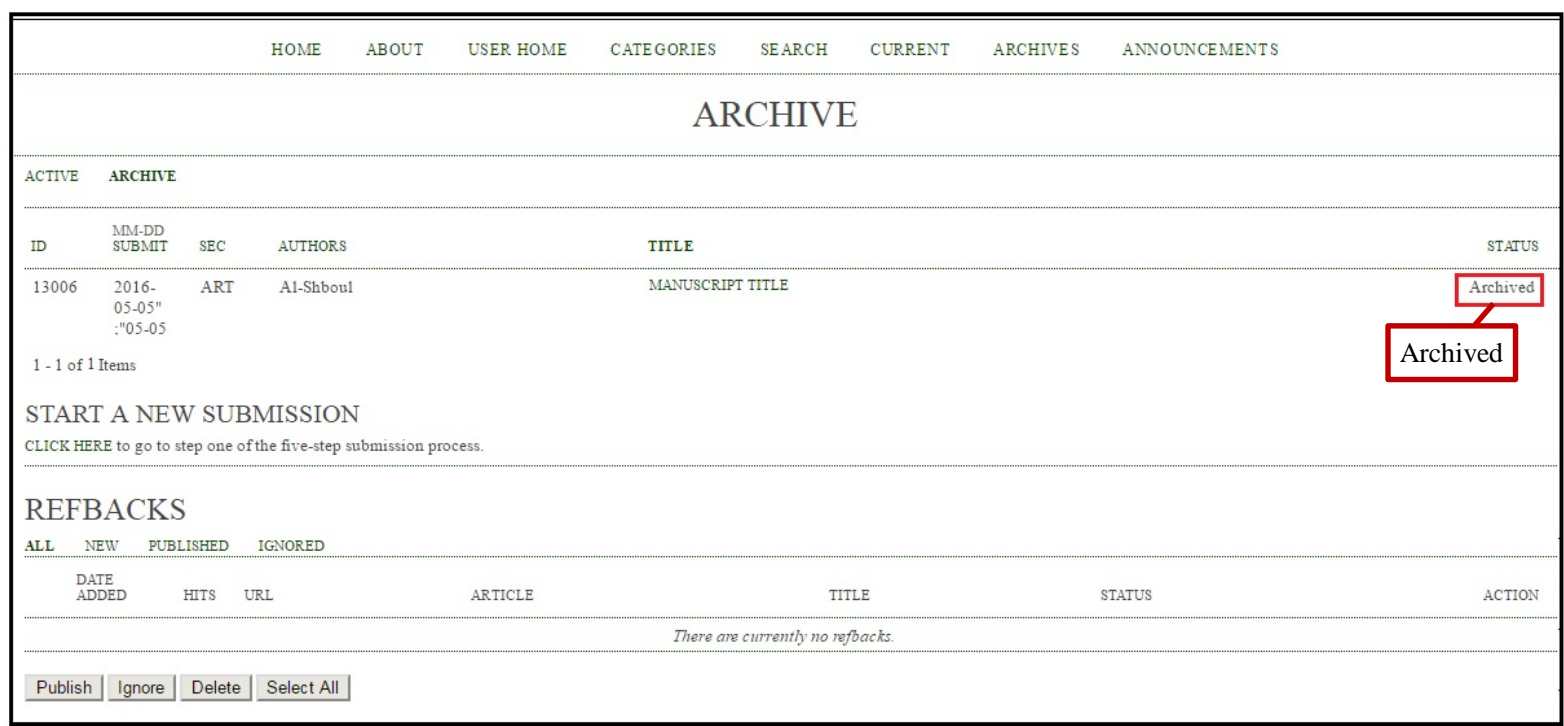

Figure 24. Archived researches.

In summary, faculty members play a vital role in the learning process and research; given that faculty members are an essential part of any technology integration at higher education institutions. However, the increasing availability of effective technology justifies investigating the level of faculty members involvement and the challenges that are associated with using these technologies. E-Publishing is a new experiment to faculty members at The University of Jordan for both the researchers and reviewers. Since the e-Publishing at The University of Jordan started in January 2013; that is, less than three and a half years, this recent experiment calls for conducting a research study to investigate the attitudes and perceptions of faculty members towards electronic-based publishing (e-Publishing which is called Online Journal Submission system (OJS)). Also, to identify factors related to the use of e-Publishing as perceived by faculty members at The University of Jordan. Thus, it is important to investigate the faculty's attitudes toward the utilization of Online Journal Submission system in their research practices as well as academic publishing. Consequently, the research topic is Faculty Members' Attitudes and Perceptions towards the Use of e-Publishing at The University of Jordan.

\section{Research Methodology}

\subsection{Research Design}

This study used mixed methods research approach, it integrating quantitative and qualitative data collection and analysis. Mixed methods research provides more comprehensive evidence for studying a research problem than either quantitative or qualitative research alone. The researcher collects data using a quantitative survey instrument (questionnaire) and follows up with semi-structured interviews with a few individuals who participated in the survey to learn more detail about their survey responses. 


\subsection{Quantitative Data Collection}

The accessible population for this study was all faculty members from the University of Jordan drawn from across all academic disciplines, who hold the rank of lecturer/instructor, assistant professor, associate professor, or full professor and who were employed full-time at the main campus. The faculty roster with a complete list of academic faculty members' names, academic rank, and faculties to which they belong to were obtained from the Human Recourses Department (HRD). Based on the information obtained from the HRD database at this university for the academic year 2015-2016, there were 1199 full-time faculty members as identified previously with different ranks. Thus, the population $(N)$ for this study was 1199. Table 2 shows the breakdown of faculty rank per faculty (college) type at this public university at the time of this study.

The sample size (n) of the study was nearly 292 faculty members from all academic disciplines at UJ. A complete list of academic faculty members' names, academic rank, and faculties to which they belong to, who have been chosen to participate in the study as either researchers or reviewers, were obtained from the Deanship of Academic Research. The 292 faculty members who represent the sample of the study have been selected randomly by implemented stratified sampling technique.

After distributing the survey to 292 participants, 197 surveys were received out of the 292; among the 197 surveys there were 7 incomplete surveys, consequently, they were dropped from the study. One hundred ninety surveys were completed and considered to be the main data for the study analysis; thus, the study response rate was 65\%. The data was collected during October and November of 2015. Table 3 shows participants representation with regard to demographic variables of the study.

On the other hand, the researcher has developed Faculty Members' Attitudes and Perceptions towards e-Publishing at The University of Jordan instrument. The instrument/questionnaire is a 39-item survey (13 items measuring faculty members' attitudes and perceptions towards e-Publishing, 14 items asking participants about the most important issues related to the use of Online Journal Submission system (OJS), and the 12 items measuring faculty members' insights on proposed statements/suggestions to improving the efficiency and effectiveness of OJS) that uses a five-point Likert-type scale ranged as follows: Strongly Agree $=5$, Agree $=4$, Neutral $=$ 3 , Disagree $=2$, Strongly Disagree $=1$. For the purpose of examining the validity of the instrument, it was presented to five experts in educational research for evaluation and educational measurement. They were asked to check whether the statements in the instrument are comments, some revisions were done to the instrument. One item deleted from attitudes and perceptions section, it becomes 13 items instead of 14; one item deleted from issues related to the use of OJS section, it becomes 14 items instead of 15; and two items deleted from suggestions to improving the use of OJS section, it becomes 12 items instead of 14. However, it is important to mention that there was one open-ended question at the end of the survey that asks the participants to make any additional comments/suggestions they would like to add or anything else they would like to mention about the use of OJS; answering this question was optional.

Table 2. Faculty rank per academic discipline $(N=1199)$.

\begin{tabular}{cccccc}
\hline Academic Discipline & Professor & Associate Professor & Assistant Professor & Lecturer/Instructor & Total \\
\hline Humanities & 114 & 118 & 99 & 164 & 495 \\
Scientific & 124 & 109 & 77 & 64 & 374 \\
Health & 72 & 75 & 116 & 67 & 330 \\
Total & 310 & 302 & 292 & 295 & 1199 \\
\hline
\end{tabular}

Table 3. Participants representation with regard to the gender, faculty rank, and academic discipline $(n=190)$.

\begin{tabular}{|c|c|c|c|c|c|}
\hline \multicolumn{2}{|c|}{ Gender } & \multicolumn{2}{|c|}{ Faculty Rank } & \multicolumn{2}{|c|}{ Academic Discipline } \\
\hline Male & 136 (71.6\%) & Professor & 35 (18.4\%) & Humanities & 80 (42.1\%) \\
\hline Female & $54(28.4 \%)$ & Associate Professor & 58 (30.5\%) & Scientific & $60(31.6 \%)$ \\
\hline \multirow[t]{3}{*}{ Total } & $190(100 \%)$ & Assistant Professor & 67 (35.3\%) & Health & $50(26.3 \%)$ \\
\hline & & Lecturer/Instructor & $30(15.8 \%)$ & Total & $190(100 \%)$ \\
\hline & & Total & 190 (100\%) & & \\
\hline
\end{tabular}


Regarding the reliability of the survey instrument, two procedures were used: Test-retest procedure (to estimate stability coefficient) and internal consistency procedure (to estimate the consistency across the items). To estimate the reliability of the instrument, to analyze its items and to examine the clearness of its statements and instructions, a pilot study had been conducted. Fifteen faculty members (represents $5 \%$ of the sample size) from the university participated in this pilot study. Those faculty members did not participate in the final study. The instructions were clear and all of the items were functioning in appropriate manner. Stability coefficients for the instrument were 0.90 . In addition, the values of Cronbach's alpha $(\alpha)$ (the internal consistency coefficient) were 0.89. The previous values can be considered reasonably satisfactory to achieve the objectives of this study.

\subsection{Qualitative Data Collection}

The interviews were conducted independently and data was collected during December 2015. Interviewees were asked about the major issues associated with faculty use of e-Publishing at The University of Jordan, in general, and key factors related to the use of e-Journals, in particular. The interviews were recorded, transcribed, edited, and qualitatively analyzed. However, to obtain the reliability and validity of interview data, the researcher has selected a large set of interviewees to minimize the awkward facts and figure bias that pertains to qualitative studies.

Fifteen interviews were conducted in-person; these interviews consisted of six researchers/authors, six reviewers, and three journals' editors. Each interview lasted on average between 25 and 35 minutes; the researcher followed the guidelines on audit interview associated with the qualitative research interview protocol. During the interview, the participants were presented with three major questions (to lead/guide the interview sub-questions): (a) How do you evaluate the experiment of e-Publishing/e-Journals (Online Journal Submission system (OJS)) at the University of Jordan? (b) What are the most issues, challenges, barriers, or obstacles that you experience when using the OJS? (c) For the purpose of improving the efficiency and effectiveness of OJS, what do you suggest to overcome these obstacles, if any, in order to successfully implement e-Publishing experiment at The University of Jordan?

After data collection, the qualitative analysis and interpretation of the narrative data were performed with reference to the main research question of the study and in accordance with the objectives of the study. Common themes across the challenges were identified from interview transcripts. Several important insights and themes associated with challenges were identified; those results and findings are reported in the following section of this paper.

\section{Data Analysis and Findings of the Study}

This section presents the results and analysis of surveys and interviews conducted in this study. These research results and findings may provide an evaluation to the current use of e-Publishing at the University of Jordan. Moreover, the results of the study might provide the decision-makers at this higher education institution with a clearly informed picture of what is currently taking place with e-Journals experiment in this academic institution. In addition, the results could offer solutions to some of the challenges and obstacles that may face the successful implementation of e-Publishing/e-Journals at this university. However, to understand the successful implementation of e-Publishing at the University of Jordan, it is necessary to know the opinions, perceptions, attitudes, impressions, and beliefs of a sample group from this scholarly institution.

The strategy is that, the surveys and interviews will identify answers to the foremost research question: "What are the key factors that may affect the successful implementation of e-Journals at The University of Jordan?” As mentioned earlier in the introduction section of the study, several reviewed studies seem to fail to focus on the unique factors that influence the successful implementation of e-Journals at higher education institutions in Jordan. Hence this study attempts to bridge that gap in knowledge.

\subsection{Findings and Analysis of Survey}

The data was analyzed using the SPSS 20.0. Means and standard deviations were analyzed for each item. An analysis of the variance three-way ANOVA comparing faculty attitudes and perceptions mean scores for each of the demographic variables was also conducted to determine whether there are any significant differences between attitudes and perceptions levels among faculty members as perceived by them for each of the demographic variables. 
There were three main research questions in this study; they were answered by using the quantitative and qualitative research methodologies. The research questions are: (a) What are the attitudes and perceptions of faculty members towards e-Publishing/e-Journals (OJS) at The University of Jordan? (b) Are there significant differences in faculty members' attitudes and perceptions towards e-Publishing/e-Journals attributed to their gender, academic rank, and academic discipline? And (c) What do faculty members believe their academic institution can do to improve the utilization of OJS at its campus?

As indicated earlier, there were 39 statements in the questionnaire on electronic scholarly journals; the followings are examples of survey items/questions that were presented to the participants to respond on them: (1) In the last five years, have you published journal articles? (2) If yes, have any of these been in electronic format or e-Journals? (3) Do you encourage and support other scholars to publish electronically? (4) Following are two suggested lists of advantages or disadvantages of electronically published or publishing scholarly articles. Please add any items to the lists. Rank each list separately with 1 as the lowest and 5 the highest or most important. (5) Do you have an account on Google Scholar Citations? (6) If yes, what is your Citation index? (6) Please respond to the following survey statements indicating your response to each item ( $5=$ strongly agree; $4=$ agree; $3=$ neutral (neither agree nor disagree); 2 = disagree; 1 = strongly disagree): (a) The peer-review process is as thorough in e-Journals as with print journals (hard copy journals); (b) Electronic publishing undermines the integrity of academic rigor; (c) Electronically published articles should be counted in the tenure and promotion process; (d) Issues relating to electronic publication are more important for tenure seeking faculty members than for tenured faculty members.

Statistical analysis of the responses of faculty members to the items that measure their attitudes and perceptions towards e-Publishing/e-Journals (OJS) revealed that the total mean scores of faculty members' attitudes and perceptions towards e-Publishing/e-Journals (OJS) was (Mean $=2.87$ ). Related to interpreted scores, attitudes and perceptions of faculty members towards e-Publishing/e-Journals were in moderate level.

Based on the results of the statistical analysis, the three most important attitudes and perceptions towards e-Publishing/e-Journals (OJS) are: (a) E-Publishing is as important as hard print publishing. (b) E-Publishing should be counted for faculty promotion. (c) E-Publishing is more important to non-tenured faculty than it is for tenured ones. On the other hand, the least attitudes and perceptions are to: (a) E-Publishing undermines the integrity of academic rigor. (b) I have never considered publishing in an e-Journal. (c) Faculty members at UJ are encouraged to experiment with e-Publications to improve teaching effectiveness and participate in academic research.

Table 4 presents three-way ANOVA results which indicate that there is a significant difference in faculty members' attitudes and perceptions towards e-Publishing/e-Journals related to their academic disciplines. This means faculty members in humanities disciplines had positive attitudes (Mean $=2.84$ ) towards e-Publishing more than faculty members in scientific and health disciplines (Mean $=2.65$ and 2.56, respectively), as shown in Table 5. Whereas, there were no significant differences in faculty members' attitudes and perceptions towards e-Publishing/e-Journals related to their gender and academic rank.

Table 4. Three-way ANOVA analysis of difference in attitudes and perceptions towards e-publishing/e-journals with faculty members grouped by gender, academic rank, and academic disciplines.

\begin{tabular}{cccccc}
\hline Source & Type III Sum of Squares & df & Mean Square & $\mathrm{f}$ & Sig. \\
\hline Gender & 0.151 & 1 & 0.151 & 0.668 & 0.415 \\
Rank & 0.363 & 3 & 0.121 & 0.534 & 0.587 \\
Discipline & 3.132 & 2 & 1.566 & 6.926 & $0.009^{*}$ \\
\hline
\end{tabular}

$$
{ }^{*} \alpha \leq 0.05 \text {. }
$$

Table 5. Means and standard deviations of faculty members’ academic disciplines.

\begin{tabular}{ccc}
\hline Academic Discipline & Mean & SD \\
\hline Humanities & 2.84 & 0.045 \\
Scientific & 2.65 & 0.057 \\
Health & 2.56 & 0.063 \\
\hline
\end{tabular}




\subsection{Findings and Analysis of Interviews}

Results from the interviewees identify challenges, problems, and barriers that may need to be overcome to support successful e-Publishing implementation at The University of Jordan. The participants were asked questions on their opinions, attitudes, and believe on awareness of e-Journals (OJS) at UJ, and the barriers which prevent the use of such new technology. However, several themes emerged from the qualitative interviews, notes made in relation to themes that emerged in each interview. These themes were categorized as follows:

- Interviewee's awareness of e-Publishing experiment at The University of Jordan: With all the fifteen faculty members (researchers, reviewers, and editors) who were interviewed there was a common thread which passed through their responses; they were of the view that Dirasat e-Journals (OJS) enhance and facilitate knowledge-transfer to the wider community of academic scholars at the national, regional, and global levels.

- The most common used journal format (electronic or print journal) at UJ: During the interview it was also found out that the available Information and Communication Technology (ICT) infrastructure at the UJ is developed enough to support the implementation and participation of e-Publishing system. This concludes that e-Journal is the most format used right now by faculty members at UJ. There was also found that electronic format is the most read when compare with the print in both health and scientific faculties. Faculty members at Scientific and Health disciplines read more prints than e-Journals; while other faculty members in humanity discipline their main source is the Web.

- Open Access issues: All of the interviewees were of the view that there are advantages and disadvantages to consider regarding e-Publishing/e-Journals. Four major issues related to Open Access Journals include: peer review, author-related publication fees, copyright and licensing, and the related practice of author self-archiving. These issues will be presented in more detailed in the Discussion section.

- Author-related benefits of Open Access journals: All of the interviewees were of the view that publishing in open access journals venues results in wider dissemination and quicker citing by other authors/researchers, thereby increasing the impact factor. Also, open access articles had both increased citation rates and were cited earlier in time, as perceived by the interviewees.

- Financial barriers of using e-Journals: Three respondents (all of the interviewees e-Journals' editors) agreed that most online journals are financially backed by an academic institution; however most operate under a deficit budget inadequate. They also stated that many journals are under considerable financial pressures for their survival and many are circulated through allocated university funds. This was from the publishers' side; on the other side, the free of charge for some e-Journals encourage the researchers to publish more articles.

- Resistance to change: In an attempted to understand how Jordanian academicians view digital scholarly publishing, the interviewees were asked about attitudes among academicians of e-Publishing. A number of the interviewees were of the view that e-Publishing is a frontier looked upon with great peculiarity in academic circles in Jordan. One of the respondents pointed out that one Jordanian scholar, for example, sees e-Publishing not in the same vein as that of print; he often demands his students to exclude electronic references from their term papers. Consequently, these attitudes do not encourage change; perceptions of publishing remain parochial.

- Scholars' attitudes about e-Journal access, use, and credibility: Several interviewees demonstrated that faculty members who utilize information technology in their daily life are more optimistic about digital technologies than other scholars. Despite the fact that those respondents believe that scholars were ready to use electronic information and e-Publishing such e-Journals, but felt that publishing in print was more credible than electronic formats.

- Potential benefits of implementing e-Publishing: Respondents were asked about the perceived advantages and disadvantages of e-Publishing/e-Journals; all of the interviewees were of the view that providing e-Journals services will reduce time, effort, and will speed up the publication process. According to the interviewees, the following are the most common advantages of e-Publishing/e-Journals: speed of publication, access-24 hours a day, convenience, quick/prompt response to ideas, information/knowledge sharing, timeliness, paperless, the ability to search text, the ability to link to additional information, and the currency of materials. These were the most important factors in choosing e-Journals over print as perceived by faculty members.

- E-Publishing implementation barriers: Respondents were asked about e-Publishing/e-Journals barriers, and they all agreed there are various barriers to e-Publishing at The University Jordan. Poor quality articles and 
not refereed were identified as the major barriers for e-Publishing implementation at the UJ. Other key barriers (the most common disadvantages of e-Publishing/e-Journals) are copyright concerns, plagiarism, lack of technical skill/training, and format not user friendly. Furthermore, respondents believe another limitation of e-Publishing implementation is that some Jordanian academicians shun it because of its distribution mode or in light of their view of its legitimacy.

- Problems or concerns with e-Publishing: From the interviews findings, several concerns related to the utilization of e-Publishing at the UJ were identified. So, the most important characteristics that would lead faculty members to choose print over e-Journals were (a) the discomfort of reading from the screen or poor graphic quality; (b) ability to browse, portability, physical comfort, and convenience; (c) lack of information technology knowledge; (d) unfamiliarity with how to access the journals; (e) a lack of need because of personal subscriptions; (f) the quality of articles in e-Journals is not the same as in print journals; (g) financial issues-since a variety of e-Journals charging publication fees; (h) technological or service problems; (i) archiving; (j) problems or confusion with information systems; (k) preferred formats for reading; (l) electronic versus print resources; (m) lack of e-Journals subscriptions; (n) lack of computer skills; (o) lack of English language skills; and (p) inadequate searching skills. These were the main perceived barriers to access of e-Journals at UJ as perceived by the interviewees.

- Age: Some interviewees affirmed that younger faculty users are more enthusiastic adopters of e-Journals than are older faculty users. Younger users rely on electronic resources more heavily and rate themselves more expert in using them than do older users.

In conclusion, the interviews confirm to a greater extent the challenges identified in the literature review as well as the problem definition such as technological problems, awareness and participation, subscriptions, training as well as intellectual property are concerns that need attention in the effective implementation of e-Publishing at the UJ as well as at higher education institutions in Jordan.

\section{Discussion}

The accessibility and the availability of information are increasing day by day in the modern world. The way of searching and delivering of information is vastly changed with the modern technology and with modern equipments. As a result, the use of e-Publishing has been increased and importance of the e-Journals provision is also highlighted by the scholars. Additionally, the new information technology has created a new infrastructure for libraries and change the way they function and provide services. The main function of a library is to provide information to the users. With the help of electronic resources faculty members, students, and the researchers can access to the huge volume of information with speed and accuracy.

Consequently, this study provides an analysis of the current state of the attitudes and perceptions towards e-Publishing and examines issues and concerns related to the use of e-Journals at the UJ. Consideration is given to both users and non-users, examining why they use or do not use this medium. The perceived advantages and disadvantages of e-Publications are also examined. The study is based on questionnaire and interview methods. A questionnaire was distributed among the users to collect desired data. A total of 292 questionnaires were distributed to the selected sample and 190 valid samples were collected. The result showed a growing interest in e-Publishing among academic users at UJ.

On the one hand, the advent of Open Access Journals has changed the landscape of accessing digital information globally. E-Journals offer valuable free, full-text, online resources for all academic-related professionals; regardless of the practice setting. Because much scholarly information may now be accessed without charge, scholars worldwide can reach a higher level of information competency-a prime requirement for evidencebased practice. On the other hand, in developing countries, higher education institutions often do not have budgets to purchase large datasets of journals and may lack access to other current information as well. Unfortunately, many universities have seen significant cuts in library budgets due to recent economic challenges. The economic downturn has resulted in publishers increasing journal prices. Given these conditions, information access is, and will continue to be, a global problem. The guiding characteristic of Open Access Journals material is that it may be accessed via the Web without charge; thus, OA offers practitioners and educators worldwide a higher level of information currency and competency.

Although many articles have been written in the past fifteen years examining the state of e-Publishing, there has been little empirical research published which examines the levels of use and acceptance of this new format within the scholarly community [25]. 
With the phenomenal growth of e-Journal publishing in academic world, this research is necessary to examine the attitudes and perceptions of faculty members at The University of Jordan towards e-Publishing experiment, which started since 2013; as well as to examine the acceptance that have occurred in these pivotal years. This study will provide the decision-makers at this higher education institution (University Administration) with information about the current amount of use of e-Journals and the acceptance level which in turn will help to determine what resources are necessary to meet present and future researchers' needs.

The initial results of this research provide evidence of the rapidly growing acceptance of e-Journals within the scholarly community at the UJ. Across all disciplines, a majority of faculty members reported that they do use e-Journals; hence, the rapid acceptance of this new format is remarkable. It is noted that the increase in e-Journal usage is accompanied by a decrease in the frequent use of print journals.

For the purpose of this study, three major research questions were investigated: (a) What are the attitudes and perceptions of faculty members towards e-Publishing/e-Journals (OJS) at The University of Jordan? (b) Are there significant differences in faculty members' attitudes and perceptions towards e-Publishing/e-Journals attributed to their gender, academic rank, and academic discipline? And (c) What do faculty members believe their academic institution can do to improve the utilization of OJS at its campus? The discussion of the findings of these research questions are presented below.

\subsection{Analysis of Respondents' Usage of E-Publishing}

Use of e-Publishing/e-Journals: In terms of the level of usage of e-Journals by faculty members at the UJ from all disciplines, out of 190 respondents, 177 use e-Journals, which is $93 \%$ of the total respondents and 13 respondents which is $7 \%$ of the total did not use e-Journals. Accordingly the majority of them use e-Journals; and at high use level.

Frequency of use e-Publishing/e-Journals: In terms of frequency of use of e-Journals by faculty members, the majority of them "often" use e-Journals and amounted 43\% (76 out of 177); $27 \%$ of them (48 out of 177) "sometimes" use e-Journals; $16 \%$ of them (28 out of 177) use "very often"; and it was able to find that $14 \%$ of them (25 out of 177) use e-Journals "rarely". The results of frequency of use of e-Journals revealed that the most of respondents "often" use e-Journals.

Purpose of using e-Publishing/e-Journals ( $\mathrm{N}=177)$ : Users' participants indicated that they have different kind of purposes of using e-Journals. The purpose of using e-Journals ranked on a four-point Likert scale ranged as highly used, moderately used, poorly used, and never used. $42 \%$ of respondents used e-Journals for publishing articles at highly used level; $45 \%$ used them to further references of their research studies at moderately used level; $9 \%$ of respondents used them as course materials to their teaching classes at poorly used level; and $4 \%$ never used them for academic use, instead they used them for personal use. Regardless of the purpose of the using e-Journals, the majority of the respondents have moderate level of use of e-Journals.

Satisfaction with e-Journals $(\mathrm{N}=177)$ : In terms of faculty members' satisfaction with e-Journals at UJ, the majority of respondents (38\%) were "satisfied" with e-Journals experiment at the UJ; $24 \%$ of them "somewhat satisfied" with e-Journals; and most significant thing is $18 \%$ of them were "highly satisfied" with e-Journals. However, $14 \%$ of them said that they "dissatisfied" with the experiment of e-Journals at UJ; and $6 \%$ of them indicated that they "highly dissatisfied" with e-Journals. The study reveals that most of them satisfied with e-Journals experiment at UJ and it is beneficial to faculty members to achieve their academic and teaching objectives with positive attitudes.

Barriers to access e-Journals ( $\mathrm{N}=177)$ : The majority of respondents $(52 \%)$ indicated that the main barrier to access e-Journals was "insufficient workstations" with bandwidth; 19\% of them indicated as obstacle of "slow internet speed"; $15 \%$ of them stated "lack of computer skills" was a barrier to access to e-Journals; while $13 \%$ of them indicated "lack of English language skills" was a barrier; and 1\% of them stated "information overload" was the barrier to use of e-Journals.

Moreover, in a question about what kind of "barriers to access" that faculty members at UJ may encounter, the majority of the respondents $(\mathrm{N}=177)$ in dictated several barriers base on a three-point Likert scale arranged as follows: "Often”, "Sometimes”, and "Never". Those barriers to access are grouped as follows: (a) "No library subscription": $60 \%$ of the participants indicated that there "Often" is no library subscription; $39 \%$ of them indicated that there "Sometimes" is no library subscription; and $1 \%$ of them indicated that there "Never" is no library subscription. (b) "Available on campus only": $22 \%$ of the participants indicated that access "Often" is 
available on campus only; $48 \%$ of them indicated that access "Sometimes" is available on campus only; and $30 \%$ of them indicated that access "Never" is available on campus only. (c) "Password needed": $18 \%$ of the participants indicated that password "Often" is needed; $49 \%$ of them indicated that password "Sometimes" is needed; and 33\% of them indicated that password "Never" is needed. And (d) "Interface difficulties": $17 \%$ of the participants indicated that they "Often" face interface difficulties; $52 \%$ of them indicated that they "Sometimes" face interface difficulties; and 31\% of them indicated that they "Never" face interface difficulties.

Hence, based on these barriers, it is suggested that the use of e-Journals at UJ should be increased for the academic purposes. Therefore orientation programs as well as training sessions should be introduced tofaculty members at UJ to enhance the usage of e-Publishing and e-Journals; which will increasing the opportunity for successful implementation of e-Publishing (OJS) experiment at UJ.

\subsection{Discussion of Research Question One Findings}

This question sought to reveal the attitudes and perceptions of faculty members towards the use of e-Publishing at the UJ. Results from the completed surveys revealed that the majority of the participants have common themes and challenges that influencing the adoption and diffusion of e-Publishing at UJ are as follows:

- Frequency of use: Questions about frequency of use for both print and e-Journals help to further define this large percentage of e-Journal readers. Half of the respondents that read e-Journals reported that they read journals in this format frequently.

- Choice of format: Respondents were asked to rate a number of characteristics of e-Journals that would affect their choice of the electronic format over print. Respondents in both reported that the characteristics of convenience, timeliness and the ability to search text were the most important factors in their choice of electronic over print. The least important characteristics in this choice were interactivity, the ability to compute, and the animation of graphics. It is possible that these characteristics are considered unimportant because they are not yet available in most e-Journals. When asked to rate characteristics that would affect their choice of the print format over electronic the most important characteristics were the ability to browse, portability, physical comfort, and convenience. The least important characteristics were familiarity with format and the ability to underline.

- Non users: Respondents that reported that they do not use e-Journals were questioned to further to explain why they do not. The results of the analysis revealed that a majority of those that do not use e-Journals do not do so because they do not know of any well-respected e-Journals in their field; in addition to a concern about the quality of e-Journals. A number of respondents (non-users) indicated that they were not resistant to using e-Journals.

- The reasons given by faculty who are not using e-Journals as to why they do not; imply an increasing resistance to change. According to respondents, the most main reasons for not using e-Publishing are as follows: "physically uncomfortable", "quality not equal”, "inadequate network resources", "the library does not subscribe", and "no knowledge of respected journals in their field".

- Implications for the electronic library: Respondents reported that the declining library budget which is a feature of so many academic institutions has put pressure on libraries to purchase "just in time" rather than "just in case". Many respondents have pointed out that the combination of budgetary constraints and developing network services have changed the library's function from a "holdings" approach to an "access" approach.

- Some remaining issues: The results of the study have largely concentrated on the scholar's needs of e-Journals. However, there are many other important considerations in the development of an e-Journal which need to be taken into account. For example, the question of copyright control is of particular concern for publishers. Although the print medium is relatively easy to copy using a photocopier, the resulting copy is of inferior quality to the original. In the electronic domain, copying is not only easy and fast but also the resulting copy is identical to the original. If someone receives an article over the network, it takes him/her no more than a few key-presses to forward a copy of the entire article to someone else. This means that either methods of electronic copy protection must be developed or the concept of copyright must be reconsidered.

- Computer knowledge: Computer skills and the attitudes of faculty users towards computing are important factors towards use and non-use of e-Journals [26]. The analysis of the study clearly showed that academic members at UJ use Web browsers and Microsoft applications frequently, and it reveals that they had positive attitudes towards the significance of computer literacy in the use of e-Journals. This explains that computer skills and computer literacy insignificantly influence the low use of e-Journals. 
- There is a modest need for training: Some respondents indicated that they would appreciate training in managing e-Journals references and locating full text from references.

- Another issue raised by some respondents, in an open-ended question, is the perceptions that e-Journals are of lower quality than print is another problem that may be diminishing as a high percentage of peer-reviewed journals are digitized. Fifty-three percent of the faculty members interviewed indicated that they did not perceive e-Journals to be of as high quality as paper counterparts; their responses changed, however, when they were asked to evaluate a well-respected print journal evolving to electronic format. On the other hand, faculty members at the University of Jordan reported that they believed e-Journal content generally to be of good quality, and in some cases, to have added value. They said that they would use more e-Journals as more were made available in their area of interest and would recommend them to students. They also reported that they have no objections to students using peer-reviewed e-Journals.

- Pay per-view issue: Pay per-use creates a barrier that affects the frequency of online access and downloads. Some respondents indicated that they may be willing to pay for electronic articles, at least part of the time. However, passwords can be another barrier to use, in particular different passwords for different databases or collections. Users want free access, without having to remember multiple passwords or log-on protocols. There is evidence that many faculty members do not realize that the numerous e-Journals they can reach from their office or home computer through their university user name or identification are actually paid for and provided by the University Library.

- Perceived advantages of e-Publishing/e-Journals and preferences: The respondents pointed out that the electronic medium offers clear advantages over print journal; faculty members' users perceive electronic resources - in particular electronic journals — to hold many advantages. The majority of the respondents cited convenience, timeliness, and the ability to search text as the most important factors in choosing e-Journals over print. Least important to them was animation of graphics, although others sometimes mention that as an important advantage. A number of studies [25] [33] have found that users believe the main advantage of e-Journals is convenience of accessing articles any time from their desktop computer. Experienced users also liked the ease of skimming and searching, the possibility of downloading or printing the desired document or segment, the currency of information, the speed of access, and the ability to send articles to their colleagues instantly. Storing articles electronically, then printing out a portable print copy, appeals to frequent e-Journal users. Furthermore, convenience and speed of access are mentioned or implied repeatedly. Respondents reported the top three ways that access to e-Journals has improved their academic careers are: access to a wider range of information, faster access to information, and easier access to information.

- Problems or concerns with e-Publishing/e-Journals: Although the advantages are outweighing the perceived problems or concerns as use increases and more resources are available, faculty users still express some concerns about the disadvantages of e-Publishing/e-Journals. The majority of participants' responses expressed the desire for more online materials, including additional journal titles, a wider variety of special or out-of-the mainstream materials, and complete volumes or back files of existing journals. Print is a proven archival format. Even those who prefer electronic access to journals prefer that books remain in print format. The most common complaint found in the reviewed literature is the discomfort of reading from the screen or poor graphic quality. Respondents consistently reported that they prefer to print out articles for reading and do most of their reading from the paper printout. They prefer PDF format for printing, although the HTML format is better for skimming. Some faculty members at UJ (OJS non-users) motioned that the most important characteristics that would lead them to choose print over electronic were ability to browse, portability, physical comfort, and convenience. Some respondents have added that print journal is an easier to read format, of better graphic quality, easier to browse, and easier to access.

- Perceived disadvantages of e-Publishing/e-Journals: A number of participants in the qualitative research interviews pointed out that, despite all these gains that e-Journals could offer, the move to digital forms of article creation and delivery has introduced challenges that no one could have anticipated. Versions of articles are proliferating. The final published versions in print are not necessarily the same as those available online. Articles are being made available earlier without page numbers, making citation problematical. Moreover, according to a number of the respondents, although there are an increasing number of e-Journals, not all of these are the subject of peer review. This raises an important issue which must be addressed by the distributors of an e-Journal that of quality control. In the print journal, the process of refereeing acts as an important quality control mechanism. While the refereeing system is open to various criticisms, it does confer an aura 
of respectability on the journals to the extent that academic status and recognition rely on publishing in such journals.

- Open Access (OA) Issues: The respondents have pointed out several issues concerning Open Access journals:

1. Author-Related Publication Fees: Using the OA model, fees are essentially eliminated for the end user and are borne on the front end. These fees are called publication fees and can range from $\$ 200$ to $\$ 1200$. Publication fee requirements for OA journals can usually be found in the "Instructions for Authors". Happily, not all OA journals charge author-related publication fees.

2. Peer Review Policies: Publications in the Open Access model still require peer review and/or quality control policies. The majority of the resources have extant peer review policies. Many use the traditional prepublication, blind, peer review model, while the most recent OA resource uses an open post-publication peer review system, in which peers can comment/review the article in an open-forum format online, and in which users can read the comments, post their own comments regarding the quality of the work, and/or respond to the comments of others.

3. Licensing and Copyright Laws: Encourages users to gain permission from the copyright holder prior to use and acknowledgment of the source. Reproduction of materials used in teaching and research are falling under the "fair use" guidelines. As OA publications continue to grow, users are faced with complying with licensing and copyright laws. Therefore, learning about licensing model, as well as the more familiar Fair Use guidelines, is not only prudent but also necessary; as to not infringe on copyright.

4. Author Archiving Policies: Authors must continue to seek efficient and effective ways to disseminate their articles so as to reach as large an audience as possible. The recent development of self-archiving has challenged the traditional system of subscription-based-journal licensing and copyright, and causes these journals to compete with free, full-text, open-access journals. In response the majority of publishers have created a system whereby authors can self-archive, regardless of the journal status regarding Open Access. Currently Open Access publishers, as well as subscription-based publishers, usually have policies regarding self-archiving. Authors need to be aware of these policies so as to derive the maximum benefit of increased citation advantage, while not infringing on copyright licenses.

- Arabic Academic journals: In a question about Arabic Academic journals, respondents indicated that there is a lack of systematic archiving as well as indexing and bibliographies that leaves many researchers in the dark about work of others, reinforcing the "legitimacy hypothesis" of many Arab Journals now being published. More stunning to most researchers is the substantial quantity of scholarship that goes unreported. For instance, accessing the full text of Master theses and Doctoral dissertations in Arab countries is often impossible without going to the source university. In addition, faculty members in higher education who are involved in some sort of research do little to produce their articles outside their local university journals.

- The editorial intensity: A few participants declared that the editorial intensity that is found in international journals is not comparable to that of indigenous Arab journals. E-Journals may go through the same process, with many of the steps of review found in traditional print journals completed electronically, where reviewers can be recruited digitally and where propitious professional relations are promoted. They also indicated that e-Publishing provides an opportunity for accelerated peer review compared to the print medium. Those respondents also argued that e-Publications are just like their relatives of print in terms of validation and acceptance. Moreover, those respondents stated that editorial work in many Arab journals is not coterminous with the professional work followed by many international journals. Local or native journals in the Arab world have a very hard time operating because of bureaucratic prerogatives bestowed to editors, who may choose articles whimsically based on academic relations.

- Language barrier: According to the majority of the respondents, language can be an obstacle to communication. It is apparent that for some academicians e-Publishing is not highly regarded. Their fears are easily interpretable. Language is an important factor to many of the scholars who write in Arabic or even approach research problems from an indigenous approach; publishing on the Web does not serve or accommodate their own style.

In summary, over the last decade, many changes have occurred in e-Publishing; many scholarly journals are now available in both in digital and print formats. Clearly, these dual formats accommodate researchers who are agile digitally or reluctant to take advantage of the Internet. However, these changes and associated publishing issues require scholars and educators to not only be aware of, but also know how to navigate new publishing 
models and create policies supportive of these new models. Scientific researchers must become involved in these changes so they do not miss out on the associated benefits personally, institutionally, and globally. The potential to create a single body of knowledge accessible to all the scientific researchers is both exciting and urgently necessary.

In short, data from the completed surveys revealed that the majority of the e-Publishing user participants generally perceive e-Journals as a positive force to achieve their teaching and research objectives. Overall, this study could be seen as one of the pioneering research on e-Publishing in Jordan and in Arab world as well. Hence, it could be a resource to future researchers in the area of e-Journals effectiveness.

Generally, information technologies have facilitated the publication of scholarship on the Web; e-Publishing is certainly improving scholarly communication. First, it breaks the tyranny of distance between authors and editors, reviewers, and researchers. Second, it enhances global scholarly communication. Third, e-Publishing provides financial advantages, eliminating many of the costs associated with printing and distribution. Fourth, e-Journals are intrinsically archival, since it is easier to store back files of journals and linked scholarship together with hyperlinks. Fifth, the substantial lower costs of digital storage mean that individual universities can maintain storage space or operate in consortia where space is shared by groups of academic institutions. Consequently, in Jordan, the University of Jordan has been a pioneer in providing access to electronic databases and e-Journals; it subscribes to e-Publications which have encouraged other universities in Jordan to follow.

Lastly, this study revealed that the use of e-Publishing/e-Journals by the faculty members at UJ was at the moderate level, this significant medium sage of e-Journals was not at the expected level; which would effectively enhance the learning and research process. These attitudes might be a result of a lack of awareness about the e-Journals or due to ineffective channels of communication in campus. Some respondents have missing values in the question about frequency of use of e-Journals; this might be explained as lack of awareness of the participants about the resources provided by the library coupled with inadequate training in ICT and searching techniques. However, the latter result was consistent with finding of previous research [26] [27].

Furthermore, the results of this survey clearly established the opinion that faculty members at UJ seem to be equipped with fairly good computer skills that enable them to search and utilize e-Journals. It emerges that the possession of computer skills only are not sufficient for efficient use of e-Journals, hence more organized training programs are needed to familiarize some of the faculty members with the e-Journals services, even though the results did not overtly show whether there was a severe lack of training or that librarians offered insufficient bibliographic instruction at the e-Library.

In addition, results of this study established that neither irrelevancy of search results due to inadequate searching neither techniques nor the slow network were explanations for the low use of e-Journals. It seems that the study has also discarded the likelihood that slow response time, and non-availability of the library Web site minimized the use of e-Journals at UJ. The low use of e-Journals at UJ may have a relationship with increasing academic teaching loads, since $90.4 \%$ of the respondents teach 12 or more than 12 hours a week. Such load may reduce the focus of faculty members on research.

Moreover, there was no significant difference in usage across the humanities faculties at the main campus, with the Faculty of Archaeology and Tourism and Faculty of Physical Education having the least usage. The latter finding was interesting and opens a window for further research to clarify this peculiar situation.

\subsection{Discussion of Research Question Two Findings}

This question sought to identify if there are any significant differences in faculty members' attitudes and perceptions towards e-Publishing/e-Journals attributed to their gender, academic rank, and academic discipline. Referring to Table 4 and Table 5, data from the completed surveys revealed that there were no significant differences in faculty members' attitudes and perceptions towards e-Publishing/e-Journals related to their gender and academic rank. Whereas, there is a significant difference in faculty members' attitudes and perceptions towards ePublishing/e-Journals related to their academic disciplines, in favour of humanities disciplines.

The results could be interpreted as the majority of the participants were from the humanities faculties, as shown in Table 3. However, given the small sample, the researcher cannot assume that this survey tells the whole story; nevertheless it provides pointers for further concerns and research. Regarding to the gender variable, the researcher believes that male and female faculty users are using e-Journals at the same level due to that both of them need to conduct a research using online journals for the promotion purposes. In regard to the aca- 
demic rank variable, the researcher assumes that all faculty members regardless of their ranks will need to use e-Publishing at the university either for their teaching or research.

About the academic discipline variable, results show that faculty members in humanities disciplines had positive attitudes towards e-Publishing more than faculty members in scientific and health disciplines. Actually, this surprising finding could be interpreted as faculty members in scientific and health disciplines might either do not have enough time to access e-Journals or they lack of technology skills, which the researcher has some doubts about it. Another reason or explanation could be attributed to that most of Dirasat journals are directed to faculty members at humanities faculties; five out of eight Dirasat journals are published purposely for faculty members in humanities disciplines: Administrative Sciences, Educational Sciences, Human and Social Sciences, Sharia, and Law Sciences. However, further research is needed to clarify this finding.

\subsection{Discussion of Research Question Three Findings}

This question sought to reveal what academic institution can do to improve the utilization of e-Publishing at its campus based on the opinions of e-Publishing/e-Journals faculty users and non-users. Data from the completed surveys and interviews revealed that the majority of the faculty member respondents indicated that their academic institution should do the following regarding the utilization of e-Publishing at UJ:

- Reduce teaching loads to make more time available for conducting academic research and participating in e-Publishing more often, and to engage in e-Publishing training.

- Offer workshops concerning the technical issues in using e-Publishing (online journal submission system).

- Offer more training sessions in the use of e-Journals services; because it was noted that e-Publishing training is both necessary and important.

- Offer adequate administrative encouragement and institutional support concerning the use of e-Publishing.

- Offer worthy rewards for using e-Journals systems.

- Offer tangible incentives for using e-Publishing, such as credit toward promotion and tenure, and recognition from the administration.

- Subscribe to more scholarly and research e-Journals.

- Provide access to well known international databases (ranked or listed in the Information Sciences Institute (ISI) Web of Knowledge, Thomson Reuters, and Scopus).

- Locate Open Access journals and categorize them according to the academic disciplines, then distribute this list to all faculty members at this university.

- Contribute in paying the publication fees for some reputed journals.

- Provide instructions to faculty members via a "User Manual” or user's guide explaining how to use UJ's Online Journal Submission System as well as how to use Google Scholar Citations.

In summary, the majority of the participants verified that this Jordanian academic institution should offer valued incentives, which could be in various forms-release time, supplemental pay, reduced faculty load, etc, in order to promote and encourage faculty members to participate in this e-Publishing experiment and to have a superior use of e-Journals at its campus. However, since the reviewed literature indicated that there is a relationship between academic institutional support and the level of faculty use of e-Publishing; that is, the more the academic institutional support, the more likely the faculty members are to use e-Journals; as well as to recruit and maintain motivated faculty members to use e-Journals, the academic institutions should offer valued incentives, eliminate obstacles, and provide equitable rewards for utilizing e-Publishing systems in teaching and research. Accordingly, it is clearly that institutional incentives, support, and encouragement are essential issues for successful implementation of new technology in higher education settings.

\subsection{Limitations of the Study}

Despite covering a large number of surveyed respondents, this study has some shortcomings. These include limited number of faculty members interviewed. This quantitative research method of the study was conducted during two months time period at UJ's main campus; whereas the qualitative research method was conducted during two weeks time period at the main campus too. As a result, very few faculty members were ready to participate in the interview process.

Another weakness is that the study focuses on one visible university. While this enables one to draw a picture of a more specific "average" scientist than examining scientists in general, how this university differs in its 
e-Publishing activities from others is not known. While it is tempting to say that this university is more open towards e-Publishing and has more extensive experience with e-Publishing than say, classicists, this is not necessarily true. Second, evidence for this visible university was found from the reviews of only two out of eight Dirasat e-Journals. As the data on the humanities journals show, reviewing data can be widely different, even within a well developed visible university. The study would be enriched by examination of the reviewing data for other e-Journals, from different disciplines, taken from different Jordanian universities. Never the less, this study meant to measure e-Publishing usage at the UJ merely.

\section{Conclusions, Implications, and Recommendations}

Academic faculty members at institutions of higher education are increasingly expected to use e-Publishing. While numerous studies [23] [24] [27] were undertaken to determine the level of use of e-Journals, this article presents several issues related to how faculty users feel about various issues surrounding e-Journals, faculty members' attitudes towards such use, ways in which they felt e-Journals had hindered or improved their academic career, and if they perceived themselves capable of using e-Publishing (Online Journal Submission system).

On the one hand, use of e-Publishing recorded huge success among academic faculty members and they demonstrated the positive impact of the e-Journals on teaching and research work. Electronic resources and information-searching skills are interrelated with the use of e-Journals. On the other hand, this study attempted to investigate faculty members' attitudes and perceptions towards e-Publishing and e-Journals at The University of Jordan.

\subsection{Conclusions}

Scholars from all academic disciplines are embracing digital journals; new issuances of journals are heavily weighted toward digital. Research scientists prefer digital journals for many reasons, including, but not limited to, the following: digital journals can be linked from and to indexing and abstracting databases; access can be from the user's home or office whether or not the physical library is open; the library can get usage statistics that are not available for print journals; and digital journals save space and are relatively easy to maintain. However, such a dramatic switch from print journals to digital journals has an impact on library users and users' perceptions of the library.

A metaphor for e-Publication allows researchers to interact directly with their peers in the absence of editorial maneuvers. It is also a lively symposium allowing reviewers, editors, and authors to work together to produce scholarship worthy of publication. Despite the advantages of e-Publishing, some Arab academics shun it because of its distribution mode or in light of their view of its legitimacy. As a result, this research study becomes handy to address the gap in the literature.

The greatest challenge that e-Publishing now faces is the acceptance among scholars. Scholars from Arab countries need to contribute to digital publications and realize the value of this medium for scholarly communication. A large number of academicians are petrified by the magnanimity of the Internet and what it bears. They often dare not to venture into this unknown, rejecting it as a vehicle for scholarly output. Arab scholars have to realize that the Internet is transforming scholarly output into a continuous dialogue between reviewers, cyberreviewers, and authors. The results empower scholars and allow them to reach an international audience, which in turn will change perceptions about Arab scholarship.

These changes in the potential global reception to Arab scholarship cannot take place without a change in the negative attitudes of Arab researchers towards e-Publishing. These attitudes and perceptions may change with training programs, improved infrastructure, and improved academic, political, and financial incentives to encourage digital scholarship.

From the one hand, e-Publishing has important advantages, compared with traditional, "print" publishing, which justifies conducting such research. These advantages (which revealed in this study) are: it is a lot of easier-it is quite easy to learn to publish electronically, and necessary equipments can be obtained without difficulties. It is much faster-it can take months to publish traditional "paper" article; it is possible to publish electronically in weeks or even days. It is less expensive-once you have software and knowledge necessary for work, you can publish lots of various materials without almost any additional costs. It can use multimedia and varying format options - an electronic article or e-Journal can have a variety of multimedia elements to add to the expe- 
rience; such elements might include music, graphics, animation, audio, or "interactivity clickable features". Downloadable formats for hand readers often include different fonts, a highlighter, post it notes, a "clickable" table of contents, and bookmarking capabilities. It will be available internationally-electronic editions can be accessed from any part of the world and read from any computer connected to the Internet.

On the other hand, the current study has showed that some faculty members are reluctance to read "online". While the popularity of e-Journals is growing steadily, many academicians are still reluctant to read onscreenor to add the cost of subscription. Regardless of age, gender, or experience, almost everyone finds it more difficult to read from a screen than from paper. The most important issues are: the ability of the eye and brain to identify and acquire information appears to work far more effectively when allied to a physical contact. Staring at a screen for any length of time induces considerably greater eyestrain than does reading an article for the same period. Many people, even very experienced computer users, feel happier with a physical, and readable, copy of what is stored in a computer system in case "something happens" to the version displayed on the screen. Relatively few desktop computers, and virtually no portable computers, can display text at a size, which is comfortable to read. It results in extensive scrolling of text, which appears to be a particularly unsettling process compared with "scrolling" of the eye over a fixed page of text.

In short, ongoing discussion and active research regarding e-Publishing issues in the academic world of the $21^{\text {st }}$ century must continue if we hope to improve the quality and relevance of academic scholarship, not only in The University of Jordan's Online Journal Submission System, but in the wider academic community also. Even without further study, the JU's Online Journal Submission System needs to come up with guidelines and policies relating to e-Publishing, promotion, and the awarding of academic tenure. The increasing reliance on e-Journals by researchers, the proliferation of titles in cyberspace, and the inability to turn the clock back to a paper-only world indicates the need. The conflict scholars face when deciding whether to seek a seemingly speedy route to publication or a slow (but possibly more valid) route is not one that encourages the spread of knowledge. Only a clear policy can rectify this ambiguous situation.

Last but not least, the researcher of this study believes that the major determinant of success of the e-Journals is their ability to satisfy the needs of the readers and authors/researchers. In general, this study may help developing countries like Jordan to exploit the potential benefits of e-Publishing to facilitate the development of research in a scientific rigor manner. It can also be said that the implementation of e-Publishing experiment at UJ has its obstacles and challenges. However, a careful review of e-Publishing and e-Journals research shows that a large portion of the published research about this topic was conducted in developed countries. In consequence, little is written about the e-Journals deployment in developing countries. Therefore, filling this gap in the literature is one of the main objectives for conducting this study in a country like Jordan.

In conclusion, the outcome of this research revealed accessibility, usability, increased communication and collaboration between authors and readers, dissemination, technologic capabilities, facilitation of scholarly work, cost, and convenience are the main advantages of the implementation of e-Publishing at The University of Jordan.

Finally, from the researcher' point of view, it is important to mention that e-Publishing may not completely replace the existing printed version but both will supplement each other in order to meet the needs of the users. So, faculty members should accept change and adapt to new situation for the benefit and interest of their needs. Thus, the university administration should recognize that the role of the library has to be redefined in view of technological development and needs to weigh all the alternatives and procure some of the documents in electronic form keeping the best interest of users and its retrieval efficiency.

\subsection{Implications}

Clearly the results of this study have implications for teaching and research generally, as well as for further research. Given the positive attitudes and perceptions towards e-Publishing demonstrated by the respondents in this study, it implies that respondents in the study are suited for a full range of e-Journals services. This is assumed that it will be fast-track the process of transforming effective and efficient teaching and research at this university. The positive attitudes and satisfactory levels with the usage of e-Journals may make respondents especially adept at creative OJS of e-Journals.

The most important implication resulting from this study involves recognizing the extent of the perceived impact of e-Journals and its effect on academic and research achievement, easy access and retrieval of informa- 
tion. It is believed that few respondents who are not skillful and experienced in the usage of e-Publishing will allow the librarians and bibliographic instructors to assist them. In addition, regular training and seminar/workshop on effective usage of e-Journals (OJS) will serve as an opportunity to provide additional assistance for academic faculty members, who find using e-Journals an intellectual challenge.

\subsection{Recommendations}

In the light of the knowledge gained from this research and the main findings that presented in this article, the following recommendations can be drawn from this study:

- The University of Jordan administration should increase the Internet bandwidth; more Internet connection bandwidth will also improve access time as the systems will work faster.

- The University of Jordan administration should increase the number of online Journal subscriptions; so it should allocate more funds to do so.

- The University administration should provide more adequate ICT training; this will enhance the utilization of e-Journals services.

- Subscriptions to print journals should be maintained; the UJ's Library should continue developing electronic collections in preference to print. Furthermore, this study indicates that for some faculty members print journals are still significant. Therefore, the Library should continue to monitor its collections' print/electronic balance and not ignore its paper copy provision.

- As the University administration should expand and maintain subscriptions to print journals; they should not ignore the importance of the role of the Open Access Journals that could play in publishing research without any extra cost.

- The University administration should facilitate quality services provided, which enhances the experience of deploying and employing e-Publishing by faculty members' users.

- To Increase e-Journals usage at UJ, the library Web page should be linked on the institutional homepage. Consequently, e-Journals should be easy to locate on the library homepage.

- Accessing e-Journals by academics and researchers at UJ primarily takes place outside the Library. Therefore, it is appropriate for the Library to consider the implications of this issue in the communication processes with the Library's user community. Thus, communication gap between librarian and faculty members should be bridged for timely flow of information.

- Improve faculty members' non-users awareness of e-Publishing, in an attempt to change the negative attitudes towards e-Publishing; this can be achieved by delivering adequate orientation programs.

- Finally, the University administration should overcome and manage resistance to change as perceived by some of the participants. This can be achieved by overcome all the barriers, obstacles, and issues related to the use of e-Publishing, in general, and e-Journals, in particular; as stated in this study.

Lastly, as future work, the researcher's next step involves conducting a large-scale survey which will explore e-Publishing adoption barriers from the end users” perspective (mainly, faculty members' non-users). Furthermore, the researcher plans to investigate and conduct more studies on the UJ's researchers ranking, UJ's top researchers publishing in ISI journals, UJ's high-impact researchers, and UJ's highly cited researchers.

\section{References}

[1] Omotayo, B. (2010) Access, Use, and Attitudes of Academics toward Electronic Journals: A Case Study of Obafemi Awolowo University, Ile Ife. Library Philosophy and Practice. http://unllib.unl.edu/LPP/omotayo.htm

[2] Manda, P. (2005) Electronic Resource Usage in Academic and Research Institutions in Tanzania. Information Development, 21, 269-282. http://dx.doi.org/10.1177/0266666905060070

[3] Okiki, O. (2012) Electronic Information Resources Awareness, Attitude and Use by Academic Staff Members of University of Lagos, Nigeria. Library Philosophy and Practice. http://digitalcommons.unl.edu/cgi/viewcontent.cgi?article=2110\&context=libphilprac

[4] Young, P. (2001) Electronic Services and Library Performance Measurement: A Definitional Challenge. Proceedings of the $4^{\text {th }}$ Northumbria International Conference on Performance Measurement in Libraries and Information Services, Pittsburgh, Pennsylvania, 12-16 August, 51-60.

[5] Herman, E. (2001) End User in Academia: Meeting the Information Needs of University Researchers in an Electronic Age. Aslib Proceedings, 53, 387-401. http://dx.doi.org/10.1108/EUM0000000007069 
[6] Sivathaasan, N., Murugathas, K. and Chandrasekar, K. (2014) Attitude towards the Usage of Electronic Information Resources in Medical Library, University of Jaffna, Sri Lanka. Information and Knowledge Management, 4, 48-57. http://www.iiste.org/Journals/index.php/IKM/article/view/10383/10748

[7] Li Liew, C., Foo, S. and Chennupati, K. (2000) A Study of Graduate Student End-Users' Use and Perception of Electronic Journals. Online Information Review, 24, 302-315. http://dx.doi.org/10.1108/14684520010350650

[8] Rajagopal, V. and Chinnasamy, K. (2012) Users’ Attitudes and Approaches towards E-Resources and Services in Academic Libraries of Puducherry Union Territory: A Study. Journal of Advances in Library and Information Science, 1, 149-152.

[9] Brennan, M., Hurd, J., Blecic, D. and Weller, A. (2002) A Snapshot of Early Adopters of E-Journals: Challenges to the Library. College and Research Libraries, 63, 515-526. http://dx.doi.org/10.5860/crl.63.6.515

[10] Sivathaasan, N., Achchuthan, S. and Kajananthan, R. (2013) Demographic Variables of University Teachers and Usage of Electronic Information Resources: A Case in Sri Lanka. International Journal of Business and Management, 8, 90-98. http://dx.doi.org/10.5539/ijbm.v8n19p90

[11] Sivathaasan, N. and Velnampy, T. (2013) Use of Electronic Information Resources and Academic Performance of University Teachers: A Case Study. European Journal of Business and Management, 5, 46-52.

http://pakacademicsearch.com/pdf-files/ech/517/46-52\%20Vol\%205,\%20No\%2014\%20(2013).pdf

[12] Gowda, V. and Shivalingaiah, D. (2009) Attitude of Research Scholars towards Usage of Electonic Information Resources: A Survey of University Libraries in Karnataka. Annals of Library and Information Studies, 56, 184-191. http://nopr.niscair.res.in/bitstream/123456789/6566/1/ALIS\%2056\%283\%29\%20184-191.pdf

[13] Herman, E. (2001) End-User in Academia: Meeting the Information Needs of University Researchers in an Electronic Age (Part 1). ASLIB Proceedings, 53, 387-401. http://dx.doi.org/10.1108/EUM0000000007069

[14] Bar-Ilan, J., Peritz, B. and Wolman Y. (2003) A Survey of the Use of Electronic Databases and Electronic Journals Accessed through the Web by the Academic Staff of Israeli Universities. Journal of Academic Librarianship, 29, 346-361. http://dx.doi.org/10.1016/j.jal.2003.08.002

[15] Tenopir, C., King, D. and Bush, A. (2004) Medical Faculty’s Use of Print and Electronic Journals: Changes over Time and in Comparison with Scientists. Journal of the Medical Library Association, 92, 233-241. http://www.pubmedcentral.nih.gov/picrender.fcgi?artid=385305\&blobtype=pdf

[16] Azubogu, N. and Madu, C. (2007) Use of Computer and Internet Technology among the Teaching Staff of Imo State University, Owerri. Heartland Journal of Library and Information Science, 1, 38-49.

[17] Oduwole A. and Akpati, C. (2003) Accessibility and Retrieval of Electronic Information at the University of Agriculture Library Abeokuta. Nigeria Library Review, 52, 228-233. http://dx.doi.org/10.1108/00242530310476742

[18] Watts, C. and Ibegbulam, I. (2006) Access to Electronic Healthcare Information Resources in Developing Countries: Experiences from the Medical Library, College of Medicine, University of Nigeria. IFLA Journal, 32, 54-61.

[19] Dhingra, D. and Mahajan, D. (2012) Electronic Journals in the University Libraries of Punjab: The Present Situation and Future Perspective. International Journal of Digital Library Services, 2, 53-69. http://dx.doi.org/10.1177/0340035206063903

[20] Prytherch, R. (2012) Harrod’s Librarians' Glossary and Reference Book: A Directory of over 10,200 Terms, Organizations, Projects and Acronyms in the Areas of Information Management, Library Science, Publishing and Archive Management. Ashgate Publishing, Ltd., London.

[21] Ludwick, R. and Glazer, G. (2000) Electronic Publishing: The Movement from Print to Digital Publication. Online Journal of Issues in Nursing, 5, 1-13. http://www.nursingworld.org/ojin/topic11/tpc11_2.htm\#Jones

[22] Jones, S. and Cook, C. (2000) Electronic Journals: Are They a Paradigm Shift? Online Journal of Issues in Nursing, 5, $1-10$.

www.nursingworld.org/MainMenuCategories/ANAMarketplace/ANAPeriodicals/OJIN/TableofContents/Volume5200 0/No1Jan00/ElectronicJournalsAreTheyAParadigmShift.aspx

[23] Tenopir, C. and King, D. (2000) Towards Electronic Journals: Realities for Scientists, Librarians, and Publishers. Special Libraries Association, Washington DC.

[24] Tenopir, C., King, D., Edwards, S. and Wu, L. (2009) Electronic Journals and Changes in Scholarly Article Seeking and Reading Patterns. ASLIB Proceedings, 61, 5-32. http://dx.doi.org/10.1108/00012530910932267

[25] Lenares, D. (1999) Faculty Use of Electronic Journals at Research Institutions. Proceedings of the Association of College and Research Libraries (ACRL) Ninth National Conference, Detroit, Michigan, 8-11 April 1999, 329-334.

[26] Bashorun, M., Isah, A. and Adisa, M. (2011) User Perception of Electronic Resources in the University of Ilorin, Nigeria (UNILORIN). Journal of Emerging Trends in Computing and Information Sciences, 2, 554-562. http://www.cisjournal.org/journalofcomputing/archive/vol2no11/vol2no11_1.pdf 
[27] Radjagopal, V. and Chinnasamy, K. (2013) Users Attitudes and Approaches towards E-Resources and Services in Academic Libraries of Puducherry Union Territory: A Study. International Review of Social Sciences and Humanities, 5, 94-104. http://irssh.com/yahoo_site_admin/assets/docs/9_IRSSH-474-V5N1.161112906.pdf

[28] Al-Shboul, M. (2013) The Level of e-Learning Integration at The University of Jordan: Challenges and Opportunities. International Education Studies, 6, 93-113. http://dx.doi.org/10.5539/ies.v6n4p93

[29] Al-Shboul, M. (2014) Faculty Members' Perceptions of E-Learning at the University of Jordan. International Journal of Instructional Technology and Distance Learning, 11, 3-44. http://www.itdl.org/Journal/Oct 14/Oct14.pdf

[30] Al-Shboul, M. and Elyan, R. (2014) e-Learning. Dar Safa for Publishing \& Distribution, Amman, Jordan.

[31] The University of Jordans Website (2016) Deanship of Academic Research. http://research.ju.edu.jo/Lists/FacultyAbstract/FacultyAbstract.aspx

[32] Al-Awawdeh, F. (2014) An Evaluation of the Experience of the Journals at the University of Jordan in the E-Publishing of the Academic Research of Faculty Members as Perceived by Researchers, Reviewers, and Journals' Editors; and Their Attitudes towards It. Master's Thesis, The University of Jordan, Amman, Jordan.

[33] Tenopir, C. (2003) Use and Users of Electronic Library Resources: An Overview and Analysis of Recent Research Studies. Council on Library and Information Resources, Washington DC. http://webdoc.sub.gwdg.de/ebook/aw/2004/pub120.pdf 